Fracture Characteristics in a

Disposal Pit on Mesita del Buey,

Los Alamos National Laboratory

Steven L. Reneau

David T. Vaniman 


\section{DISCLAIMER}

This report was prepared as an account of work sponsored by an agency of the United States Government. Neither the United States Government nor any agency thereof, nor any of their employees, make any warranty, express or implied, or assumes any legal liability or responsibility for the accuracy, completeness, or usefulness of any information, apparatus, product, or process disclosed, or represents that its use would not infringe privately owned rights. Reference herein to any specific commercial product, process, or service by trade name, trademark, manufacturer, or otherwise does not necessarily constitute or imply its endorsement, recommendation, or favoring by the United States Government or any agency thereof. The views and opinions of authors expressed herein do not necessarily state or reflect those of the United States Government or any agency thereof. 


\section{DISCLAIMER}

Portions of this document may be illegible in electronic image products. Images are produced from the best available original document. 


\title{
FRACTURE CHARACTERISTICS IN A DISPOSAL PIT ON MESITA DEL BUEY, LOS ALAMOS NATIONAL LABORATORY
}

\author{
by
}

\author{
Steven L. Reneau and David T. Vaniman
}

\begin{abstract}
The characteristics of fractures in unit 2 of the Tshirege Member of the Bandelier Tuff were documented in Pit 39, a newly excavated $13.7 \mathrm{~m}$ deep disposal pit at Material Disposal Area $\mathrm{G}$ on Mesita del Buey. The average spacing between fractures is about 1.0 to $1.3 \mathrm{~m}$, the average fracture aperture is about 3 to $5 \mathrm{~mm}$, and the average fracture dip is about $76^{\circ}$ to $77^{\circ}$. Fracture spacing and dip in Pit 39 are generally consistent with that reported from other fracture studies on the Pajarito Plateau, although the fracture apertures in Pit 39 are less than reported elsewhere. Measured fracture orientations are strongly affected by biases imparted by the orientations of the pit walls, which, combined with a small data set, make identification of potential preferred orientations difficult. The most prominent fracture orientations observed in Pit 39, about E-W and N20E, are often not well represented elsewhere on the Pajarito Plateau. Fracture fills contain smectite to about $3 \mathrm{~m}$ depth, and calcite and opal may occur at all depths, principally associated with roots or root fossils (rhizoliths). Roots of piñon pine extend in fractures to the bottom of the pit along the north side, perhaps indicating a zone of preferred infiltration of water. Finely powdered tuff with clay-sized particles occurs within a number of fractures and may record abrasive disaggregation associated with small amounts of displacement on minor local faults.
\end{abstract}

\section{INTRODUCTION}

A study of fractures in Pit 39, Material Disposal Area (MDA) G, Technical Area (TA) 54 (Fig. 1), was conducted in 1992 to provide additional data on fracture characteristics on this mesa as part of Los Alamos National Laboratory (LANL) Environmental Restoration Project site characterization activities. These fractures are inferred to be an important part of the vadose zone hydrologic system (e.g., Neeper and Gilkeson, 1996; Turin and Rosenberg, 1996), and the data presented in this study were collected in order to assist the development and application of conceptual and numerical models for the vadose zone.

Pit 39 is located on Mesita del Buey at an elevation of about $6730 \mathrm{ft}(2050 \mathrm{~m})$, and was excavated in 1992 to a depth of about $45 \mathrm{ft}(13.7 \mathrm{~m})$, crossing the boundary between two ash flows within unit 2 of the Tshirege Member of the Bandelier Tuff (using the nomenclature of Broxton and Reneau, 1995; equivalent to unit $2 \mathrm{~b}$ of Purtymun and Kennedy, 1971, and unit $C$ of Rogers, 1995). The boundary between these two ash flows is marked by discontinuous surge beds that are similar to those occurring at the base of unit 2. Survey data from the south edge of Mesita del Buey (Reneau et al., 1998) suggest that virtually the full thickness of unit 2 is represented in the pit walls. Data were collected from both of the unit 2 flow units, allowing a comparison of fracture characteristics across this stratigraphic boundary, although a more thorough characterization was performed of the fractures in the lower pit because these were considered most relevant for possible transport of moisture or contaminants. In addition, measurements were made on both east-west and north-south trending walls, allowing possible biases introduced by wall orientation to be examined. These data are compared with other 


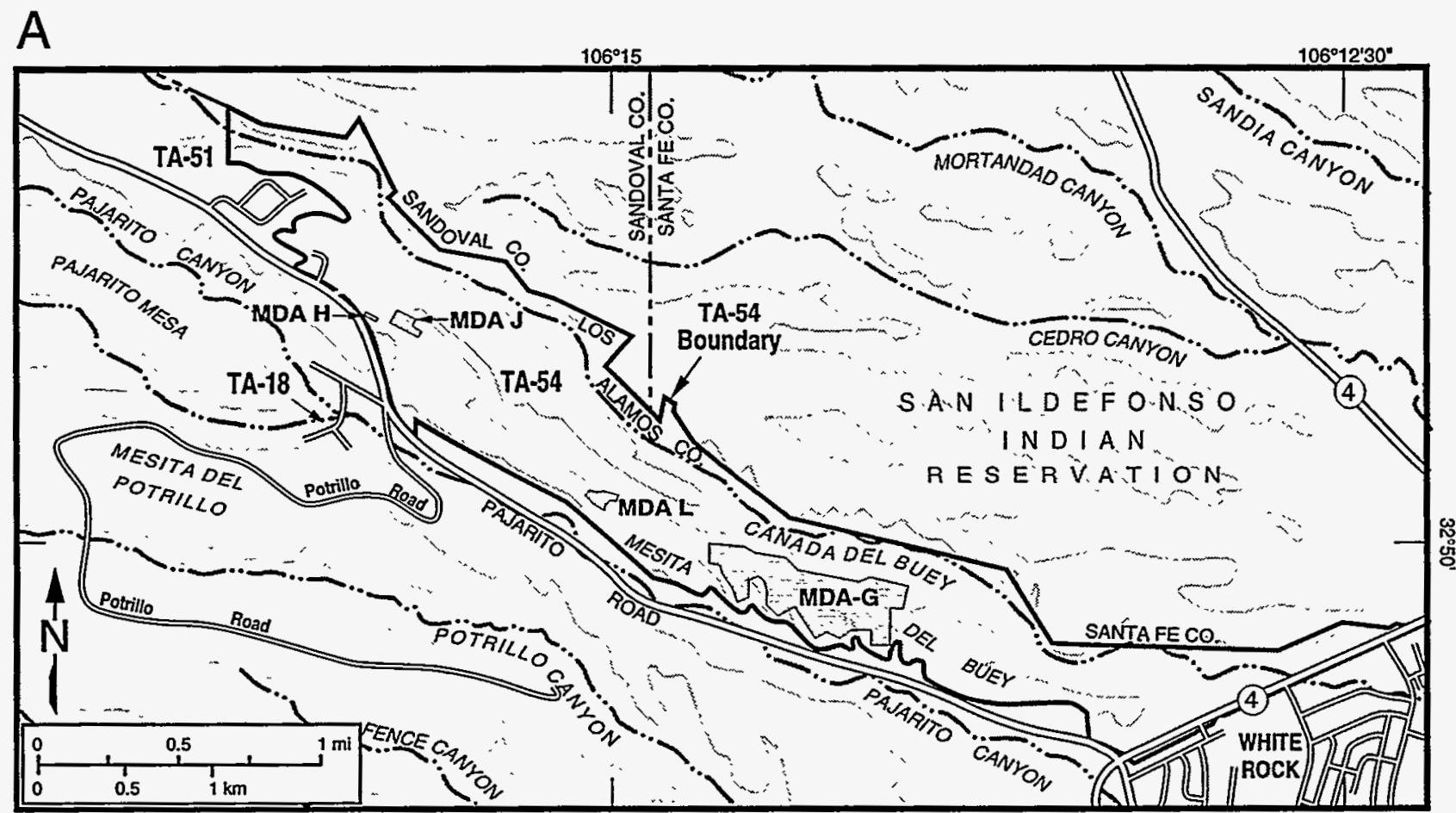

B

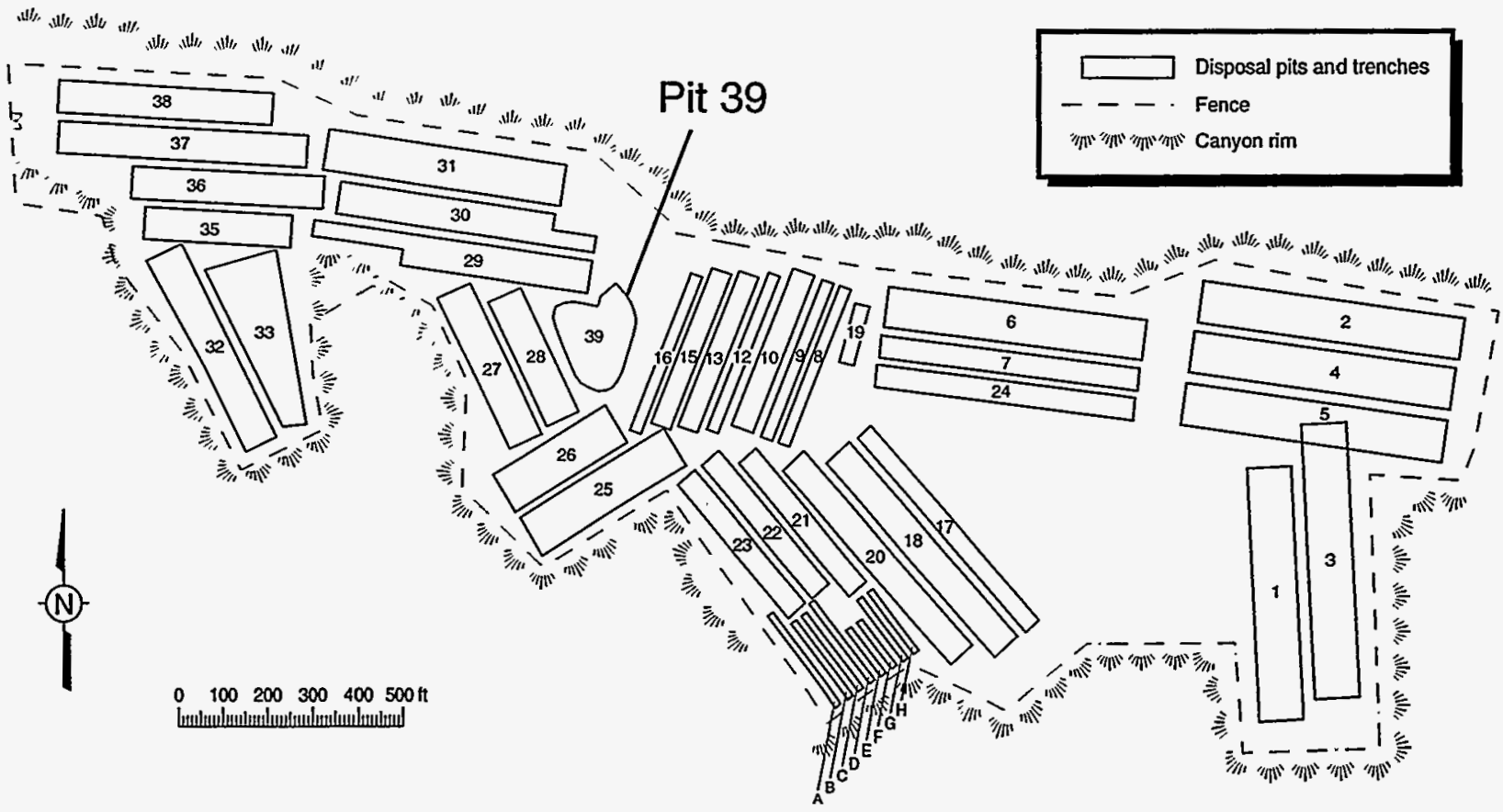

Fig. 1. (A) Map showing location of MDA G at TA-54. (B) Location of Pit 39 within MDA G. 
fracture data collected on the Pajarito Plateau to examine to what degree the Pit 39 data may be representative of other sites.

\section{METHODS}

Fractures were mapped onto a 1-ft contour map of Pit 39 provided by LANL group EM-7, plotted at a scale of 1:132.5 (Fig. 2). All of the lower walls and about half of the upper walls of Pit 39 were mapped. As discussed in this report, the upper wall is equivalent to the upper flow unit exposed in Pit 39, and the lower wall is equivalent to the lower flow unit. For accessible and well-exposed fractures, measurements were made of fracture orientation, dip, and aperture, and notes were made on fracture filling materials and roots. Measurements were not made on some fractures that were inaccessible on the pit walls. In addition,

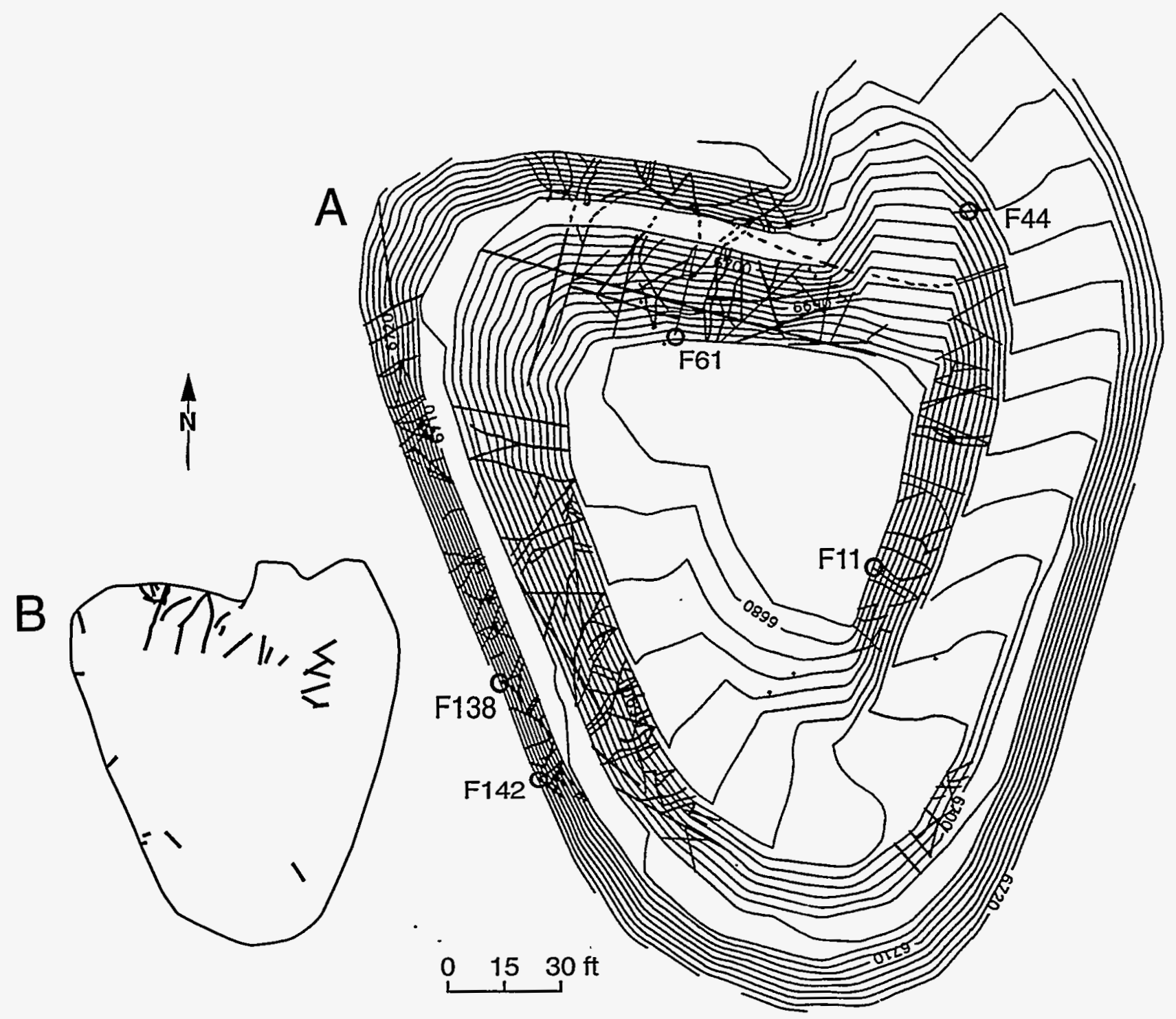

Fig. 2. (A) Topographic map of Pit 39, showing mapped fractures and locations of samples discussed in text. The contour interval is $2 \mathrm{ft}$, and the topographic base map was provided by EM-7. (B) Map of Pit 39, indicating mapped fractures in which living roots or root fossils occur (heavier lines). Note the concentration of these occurrences in the northern portion of the pit and at depths extending at least to the bottom of the pit. This concentration may indicate a zone of preferred migration for surface water penetrating into the mesa, prior to pit excavation. 
parts of the pit walls consisted of highly broken rock that was at least partially caused by pit excavation, and measurements were not made if such secondary fractures were suspected. Consequently, some zones of highly fractured tuff were probably not recognized, and the measurements of fracture density may be somewhat underestimated. In addition to the field measurements of fracture characteristics, representative samples of fracture filling materials and roots were collected for X-ray diffraction (XRD) and scanning electron microscope (SEM) analyses to examine their mineralogy and chemistry.

\section{FRACTURE CHARACTERISTICS AT PIT 39 AND COMPARISON WITH OTHER SITES}

\section{Fracture Density}

Pit 39. Fracture density was measured along 17 horizontal transects along the east, north, and west walls of Pit 39, on both the upper and lower walls, and along 70 sloping transects down the pit walls. The horizontal transects provide data comparable to horizontal core holes and the sloping transects provide data comparable to inclined core holes.

For the horizontal transects, the average fracture spacing ranged from 3.2 to $4.2 \mathrm{ft}(1.0$ to $1.3 \mathrm{~m}$ ) along these transects, and the median fracture spacing ranged from 1.9 to $4.0 \mathrm{ft}(0.6$ to $1.2 \mathrm{~m})$ (Table 1). Maximum horizontal distance between fractures was $14 \mathrm{ft}(4.3 \mathrm{~m})$. Frequency distributions of horizontal fracture spacing measurements from each wall are shown in Figure 3.

Slight differences are noted between the horizontal fracture spacing on different walls of Pit 39. On both the lower and upper walls, both average and median fracture spacing is slightly higher on the E-W wall than on the N-S walls (Table 1, Fig. 3). This may be due to the apparent dominance of an E-W fracture set. In addition, although average fracture spacing is similar between the upper and lower walls, median spacing is greater on the lower walls. This reflects a more highly skewed distribution on the upper walls, with both a larger percentage of fracture spacings under $2 \mathrm{ft}(0.6 \mathrm{~m})$ and a larger maximum fracture spacing.

For the sloping transects, fractures were intersected less frequently than for the horizontal transects, reflecting the steeply dipping nature of most of the fractures. For the upper wall, including the upper $15 \mathrm{ft}(4.6 \mathrm{~m})$ of the pit, 0 to 6 fractures were encountered along transects that averaged 20 to $21 \mathrm{ft}(6.1$ to $6.4 \mathrm{~m}$ ) in length (Table 2). The average number of fractures encountered was similar on both the west and north walls, at 2.7 to 2.8 per transect. For the lower wall, including the lower 21 to $25 \mathrm{ft}$ ( 6.4 to $7.6 \mathrm{~m}$ ) of the pit, 1 to 6 fractures were measured along transects that averaged 26 to $32 \mathrm{ft}$ ( 7.9 to $9.8 \mathrm{~m}$ ) in length (Table 2). The average number of fractures encountered ranged from 1.9 on the lower east wall to 4.5 on the lower north wall. A possible relationship between the orientation of the transect and the number of fractures encountered is consistent with data on fracture dip, discussed later, that suggests a preferential dip to the west or northwest in the lower walls.

Other Pajarito Plateau Studies. Purtymun et al. (1978) reported fracture data obtained from horizontal core holes beneath Pit 3, east of Pit 39 in MDA G (Fig. 1b). Most of the data were obtained from the lower part of their unit $2 b$ (unit 2 of Broxton and Reneau, 1995), with some of the data from the upper part of their unit 2a (the uppermost part of unit $1 v$ of Broxton and Reneau, 1995). The average fracture spacing of 3.0 to $5.6 \mathrm{ft}(0.9$ to $1.7 \mathrm{~m}$ ) that they reported is consistent with the 3.2 to $4.2 \mathrm{ft}(1.0$ to $1.3 \mathrm{~m})$ average spacing measured in Pit 39. In contrast, other data from TA-54 indicate more widely spaced fractures. Purtymun et al. (1978) reported that the average fracture spacing measured within Pit 3 was $7.2 \mathrm{ft}(2.2 \mathrm{~m})$, and they attribute this difference from the core data as probably due to incomplete mapping of minor fractures on the pit walls. Similarly, Purtymun and Kennedy (1971) reported average fracture spacing at MDA G to be about $7 \mathrm{ft}(2.1 \mathrm{~m})$, and data from individual MDA $G$ pits, summarized by Rogers (1977), indicate a range of average spacings of 
Table 1. Summary of Horizontal Fracture Spacing Measurements.

\begin{tabular}{|c|c|c|c|c|}
\hline Transect & $\begin{array}{l}\text { Number } \\
\text { of } \\
\text { Fractures }\end{array}$ & $\begin{array}{c}\text { Total } \\
\text { Distance } \\
\text { (ft) }\end{array}$ & $\begin{array}{c}\text { Average } \\
\text { Spacing } \\
\text { (ft) }\end{array}$ & $\begin{array}{c}\text { Median } \\
\text { Spacing } \\
\text { (ft) }\end{array}$ \\
\hline $\begin{array}{l}\text { Lower E } \\
-43^{\prime} \mathrm{E} \\
-41^{\prime} \mathrm{E} \\
-39^{\prime} \mathrm{E} \\
-36^{\prime} \mathrm{E} \\
\text { average }\end{array}$ & $\begin{array}{l}20 \\
20 \\
23 \\
21\end{array}$ & $\begin{array}{l}70.5 \\
77.3 \\
82.9 \\
79.4\end{array}$ & $\begin{array}{l}3.7 \\
4.1 \\
3.8 \\
4.0 \\
3.9\end{array}$ & $\begin{array}{l}3.3 \\
3.7 \\
3.2 \\
2.5 \\
3.2\end{array}$ \\
\hline $\begin{array}{l}\text { Lower N } \\
-43^{\prime} \mathrm{N} \\
-41^{\prime} \mathrm{N} \\
-39^{\prime} \mathrm{N} \\
-36^{\prime} \mathrm{N} \\
\text { average }\end{array}$ & Vall $\begin{array}{r}15 \\
16 \\
19 \\
22\end{array}$ & $\begin{array}{l}59.2 \\
61.5 \\
64.8 \\
83.7\end{array}$ & $\begin{array}{l}4.2 \\
4.1 \\
3.6 \\
3.9 \\
4.0\end{array}$ & $\begin{array}{l}4.0 \\
3.5 \\
3.3 \\
3.7 \\
3.6\end{array}$ \\
\hline $\begin{array}{l}\text { Lower V } \\
-38^{\prime} \mathrm{W} \\
-36^{\prime} \mathrm{W} \\
-34^{\prime} \mathrm{W} \\
\text { average }\end{array}$ & $\begin{array}{l}22 \\
30 \\
37\end{array}$ & $\begin{array}{c}79.6 \\
97.4 \\
119.2\end{array}$ & $\begin{array}{l}3.8 \\
3.4 \\
3.3 \\
3.4\end{array}$ & $\begin{array}{l}2.8 \\
2.4 \\
2.6 \\
2.6\end{array}$ \\
\hline $\begin{array}{l}\text { Upper W } \\
-1^{\prime} \mathrm{W} \\
-11^{\prime} \mathrm{W} \\
-9^{\prime} \mathrm{W} \\
\text { average }\end{array}$ & $\begin{array}{l}42 \\
46 \\
47\end{array}$ & $\begin{array}{l}146.6 \\
147.2 \\
146.6\end{array}$ & $\begin{array}{l}3.6 \\
3.3 \\
3.2 \\
3.3\end{array}$ & $\begin{array}{l}2.4 \\
2.0 \\
1.9 \\
2.1\end{array}$ \\
\hline $\begin{array}{l}\text { Upper N } \\
-17^{\prime} \mathrm{N} \\
-15^{\prime} \mathrm{N} \\
-13^{\prime} \mathrm{N} \\
\text { average }\end{array}$ & $\begin{array}{l}\text { Tall } \\
18 \\
21 \\
19\end{array}$ & $\begin{array}{l}71.3 \\
70.7 \\
69.6\end{array}$ & $\begin{array}{l}4.2 \\
3.5 \\
3.9 \\
3.8\end{array}$ & $\begin{array}{l}2.6 \\
2.7 \\
2.2 \\
2.5 \\
\end{array}$ \\
\hline
\end{tabular}

about 6 to $9 \mathrm{ft}(1.8$ to $2.7 \mathrm{~m})$. In addition to larger average fracture spacing having been reported from most MDA G pits than from Pit 39, previously reported data also indicate higher maximum fracture spacing. As one example, data of Trocki (1976) from Pit 20 at MDA G are shown in Figure 4, with an average fracture spacing of $8.3 \mathrm{ft}$ $(2.5 \mathrm{~m})$ and a maximum spacing of $30 \mathrm{ft}(9.1 \mathrm{~m})$ (Fig. 4). The reason for the discrepancy between the data from Pit 39 and from the other MDA G pits is not certain, but it may in part result from a more complete mapping of the minor fractures in Pit 39, as suggested by Purtymun et al. (1978) to explain the smaller fracture spacing measured in the Pit 3 cores, or it may perhaps indicate great spatial variability in fracture density.

Farther west on the Pajarito Plateau, average fracture spacings of about 0.9 to $1.2 \mathrm{~m}$ were reported from trenches on Pajarito Mesa (Kolbe et al., 1994; Reneau et al., 1995), similar to that found in Pit 39, and higher values of about $1.7 \mathrm{~m}$ were reported from trenches in TA-3 (Purtymun et al., 1995). Studies of fractures in cliff faces in Los Alamos Canyon reported typical average fracture spacing of about 1.4 to $1.5 \mathrm{~m}$, locally decreasing to 0.4 to $0.8 \mathrm{~m}$ (Wohletz, 1995, 1996). Studies that focus on what are judged to be the most continuous fractures indicate higher average spacing. For example, the subset of the Pajarito Mesa fractures that were identified on opposite trench walls ("through-going fractures") had average spacings of about 2.2 to $3.2 \mathrm{~m}$ (Kolbe et al., 1994; Reneau et al., 1995), and fractures that were observed to pass from welded into nonwelded tuff on the side of Pajarito Mesa ("mesa-penetrating fractures") had average spacings of about 4.1 to $6.1 \mathrm{~m}$ (Vaniman and Chipera, 1995). 

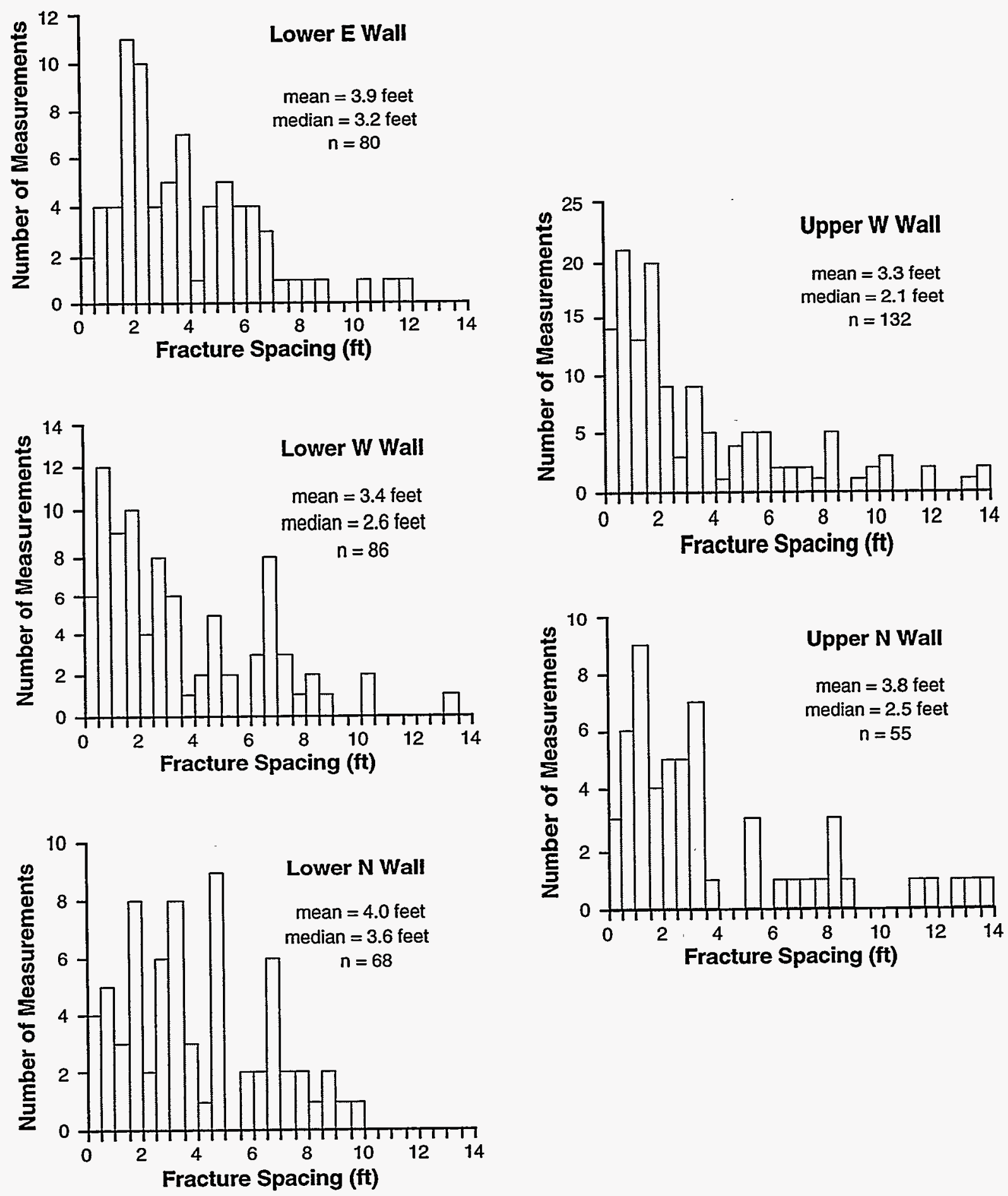

Fig. 3. Frequency distributions of fracture spacing measurements along horizontal transects in Pit 39.

\section{Fracture Aperture}

Pit 39. Fracture apertures are similar between all measured Pit 39 transects, showing relatively little variability. Median apertures ranged from 2 to $4 \mathrm{~mm}$, with a typical value of $3 \mathrm{~mm}$ for both the upper and lower walls. However, wider fractures were measured on the lower walls than on the upper walls, with a maximum of $100 \mathrm{~mm}$ on the lower walls contrasting with a maximum of $13 \mathrm{~mm}$ on the upper walls, and the mean aperture is greater on the lower walls (Fig. 5). For all fractures on the lower walls, the mean aperture is $5.3 \pm 11.1 \mathrm{~mm}$, and for all fractures on the upper walls, the mean 
Table 2. Summary of Inclined Fracture Spacing Measurements.

\begin{tabular}{lcccccc}
\hline & $\begin{array}{c}\text { Average } \\
\text { Wall } \\
\text { Wumber of } \\
\text { Meight } \\
\text { Measurements }\end{array}$ & $\begin{array}{c}\text { Average } \\
\text { Slope } \\
\text { Length } \\
\text { (ft) }\end{array}$ & $\begin{array}{c}\text { Average } \\
\text { Slope } \\
\text { Angle } \\
\text { (degrees) }\end{array}$ & $\begin{array}{c}\text { Number of } \\
\text { Fractures } \\
\text { Intersected } \\
\text { (range) }\end{array}$ & $\begin{array}{c}\text { Number of } \\
\text { Fractures } \\
\text { Intersected } \\
\text { (average) }\end{array}$ \\
\hline Lower East & 13 & 21 & 26 & 53 & $1-4$ & $1.9 \pm 1.0$ \\
Lower West & 14 & 24 & 30 & 53 & $2-5$ & $3.4 \pm 1.0$ \\
Lower North & 14 & 25 & 32 & 51 & $3-6$ & $4.5 \pm 0.9$ \\
& 14 & 19 & 21 & 64 & $0-6$ & $2.8 \pm 1.8$ \\
Upper West & 14 & 16 & 20 & 54 & $1-5$ & $2.7 \pm 1.2$ \\
UpperNorth & 15 & & & & & \\
\hline
\end{tabular}

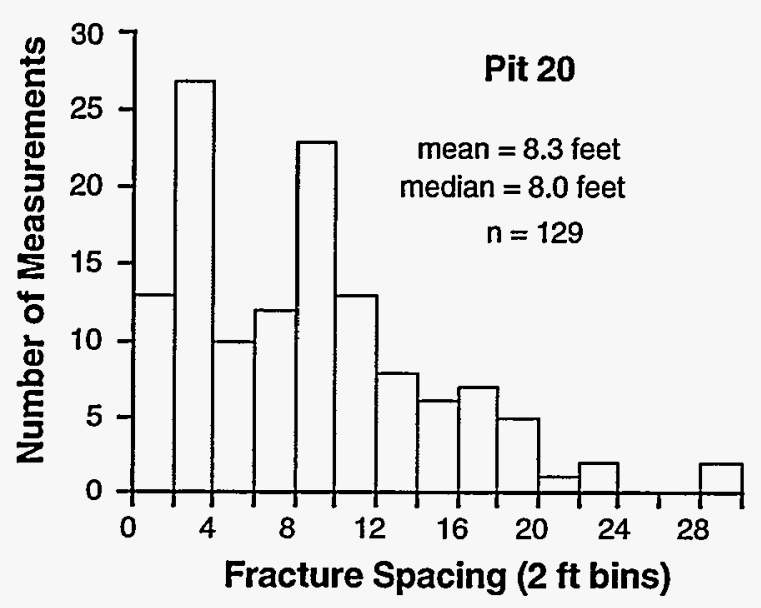

Fig. 4. Frequency distribution of fracture spacing in Pit 20, MDA G. Data from Trocki (1976).

aperture is $3.1 \pm 2.1 \mathrm{~mm}$. Only $6 \%$ of the fractures are open $10 \mathrm{~mm}$ or greater, with the largest opening of $100 \mathrm{~mm}$. Using an average fracture aperture of $4 \mathrm{~mm}$ and an average fracture spacing of about $3.7 \mathrm{ft}(1.1 \mathrm{~m})$, fractures occupy less than $0.5 \%$ of the walls.

Other Pajarito Plateau Studies. Fracture aperture data from MDA $G$ were previously summarized by Purtymun and Kennedy (1971), who reported that fracture openings reached 2 inches $(51 \mathrm{~mm})$, with most less than 0.25 inches $(6.4 \mathrm{~mm})$. These values appear to be consistent with the Pit 39 data presented in this report, with average apertures of about 3 to $5 \mathrm{~mm}$. In contrast, most other studies elsewhere on the Pajarito Plateau have reported greater average apertures. Vaniman and Wohletz (1990) reported average fracture apertures of $18 \mathrm{~mm}$ in roadcuts along Pajarito Road west of
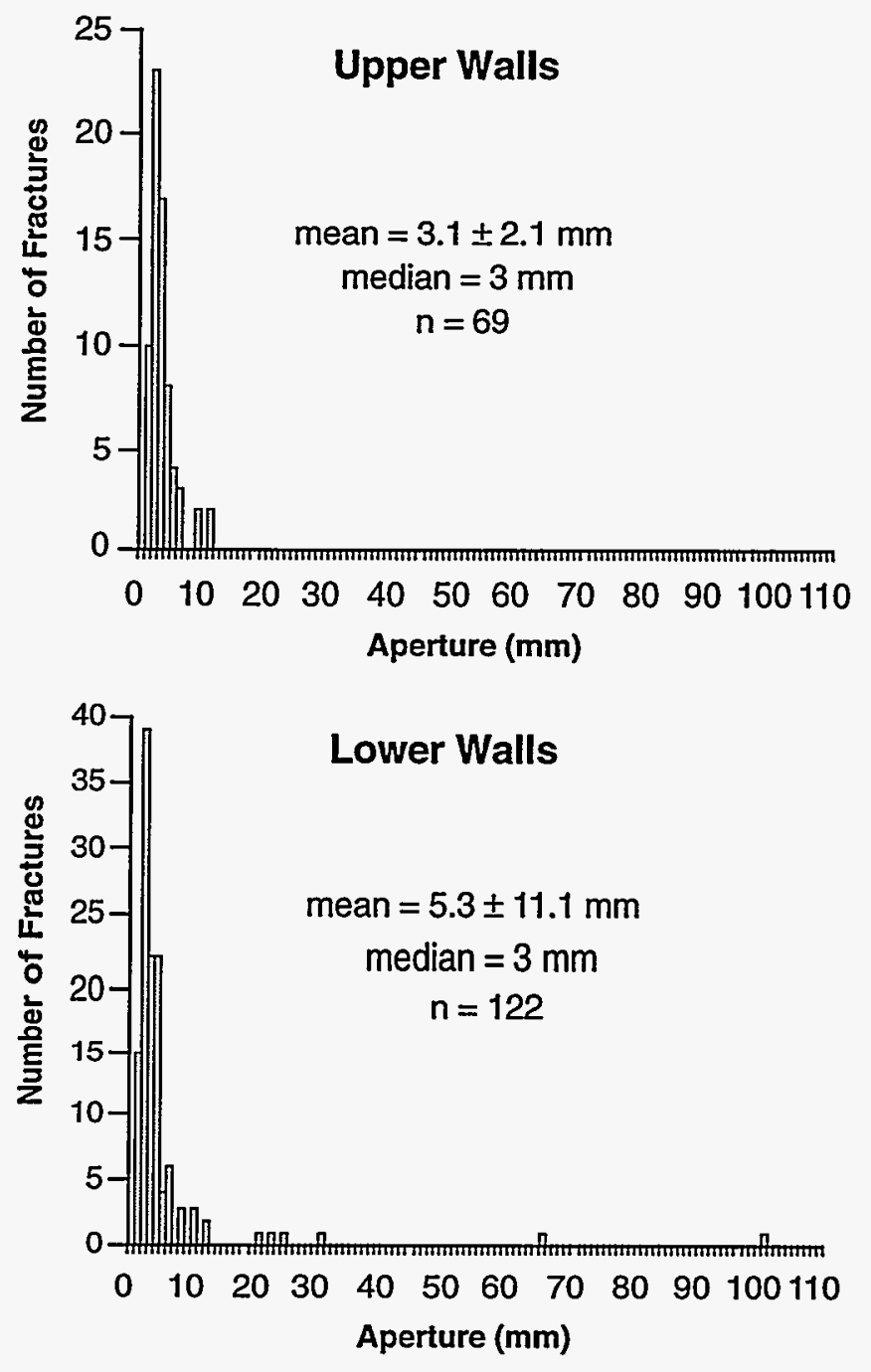

Fig. 5. Frequency distributions of fracture apertures in Pit 39.

TA-54 and $9 \mathrm{~mm}$ along East Jemez Road, in units of the Bandelier Tuff stratigraphically above the units at TA-54. Wohletz $(1995,1996)$ reported background apertures averaging 7 to $8 \mathrm{~mm}$ along the walls of Los Alamos Canyon, and apertures 
averaging 10 to $13 \mathrm{~mm}$ within broad zones of higher fracture density. The average width of through-going fractures in trenches on Pajarito Mesa is about $2 \mathrm{~cm}$ (Kolbe et al., 1994; Reneau et al., 1995), and is similar to average fracture widths of about 1 to $2 \mathrm{~cm}$ in trenches at TA-63 (Kolbe et al., 1995) and TA-3 (Purtymun et al., 1995).

The reasons for the apparently lower fracture apertures in Pit 39 as compared to sites farther west on the Pajarito Plateau are not certain. Possible causes for wider fractures to the west include (1) greater cooling contraction in more welded units to the west, and (2) more tectonic extension to the west, closer to the Pajarito fault zone. It is also possible that fractures tend to become more open near cliff faces and mesa edges, as suggested by some workers (Conover, 1956, cited in Rogers, 1977, p. G-1; Kolbe et al., 1995), although this should not apply to trenches excavated near the centers of mesas.

\section{Fracture Orientation}

Pit 39. A significant bias is apparent in the data on fracture orientation at $\mathrm{Pit} 39$, reflecting the different orientations of the measured walls. Specifically, E-W fracture sets are most apparent in the east and west walls, which have general $\mathrm{N}-\mathrm{S}$ orientations, and $\mathrm{N}$-S fracture sets are most apparent in the north wall. These biases can be seen in rose diagrams of fracture azimuths plotted separately for each wall (Fig. 6). The existence of such an inherent bias imparted by the nonrandom orientation of measured exposures has long been recognized (e.g., Terzaghi, 1965), and corrections for this bias are needed to derive accurate data on preferred fracture sets. In this study, two methods were attempted to correct for this bias, as presented below.

The first method for correcting the fracture orientation data assumed that combining measurements from both the E-W and N-S trending walls into one data set would approximate a random distribution. Upper and lower walls were treated separately, and the data from E-W walls and $\mathrm{N}-\mathrm{S}$ walls were weighted equally so that the larger number of fractures measured on N-S trending walls would not dominate the results. The most common fracture orientations on the lower wall are roughly E-W ( $95^{\circ}$ azimuth, or $\mathrm{N} 85 \mathrm{~W}$ ), $\mathrm{N}-\mathrm{S}\left(15^{\circ}, \mathrm{N} 15 \mathrm{E}\right)$, and NE-SW $\left(65^{\circ}, \mathrm{N} 65 \mathrm{E}\right)$ (Fig. 7). The most common orientations on the upper wall are roughly NE-SW $\left(50^{\circ}, \mathrm{N} 50 \mathrm{E}\right), \mathrm{E}-\mathrm{W}$ $\left(85^{\circ}, \mathrm{N} 85 \mathrm{E}\right)$, and NW-SE $\left(135^{\circ}, \mathrm{N} 45 \mathrm{~W}\right)$ (Fig. 7). Combining the data sets for the upper and lower walls, again weighting each equally, suggests fracture sets at about $20^{\circ}(\mathrm{N} 20 \mathrm{E}), 50^{\circ}(\mathrm{N} 50 \mathrm{E})$, and $95^{\circ}$ (N85W) (Fig. 7), although the small number of fractures measured on some walls limits the confidence in these values.

The second method for correcting for wall orientation uses an equation provided by Terzaghi (1965):

$$
\mathrm{N}_{90}=\mathrm{N}_{\alpha} / \sin \alpha,
$$

where $\mathrm{N}_{90}$ is the number of fractures that would have been intersected in an exposure oriented $90^{\circ}$ to the fracture set, and $\mathrm{N}_{\alpha}$ is the number of fractures intersected in an exposure oriented at an angle $\alpha$ to the fracture set. This equation was applied to the data sets from each wall separately to check for the reliability of this correction. Theoretically, if the data sets are large enough to provide an accurate sample of fractures in each data set, the corrected fracture distributions from walls with different orientations should be similar. As presented in Figure 8, it is apparent that the corrected data sets do not completely agree, probably reflecting the relatively small number of measured fractures on some walls. For example, the apparent dominance of an E-W fracture set in the lower $\mathrm{N}$ wall is produced by four fractures that intersect this wall at a very low angle.

The fracture orientation data for each wall, corrected for wall orientation, are summarized in Figure 9. Comparing these data with the data summarized in Figure 7 indicates that both methods of adjusting the fracture data for biases show fracture sets centered at about $95^{\circ}(\mathrm{N} 85 \mathrm{~W})$ and $20^{\circ}$ (N20E), supporting the existence of significant fracture sets with these orientations. Possible 


\section{Upper W Wall}

$\mathrm{n}=55$

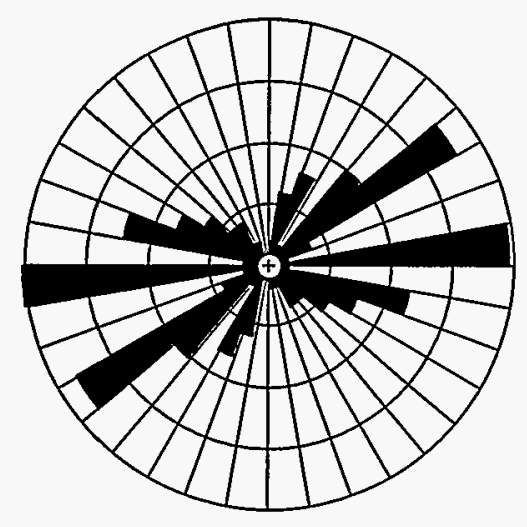

Lower $E+W$ Walls

$\mathrm{n}=92$

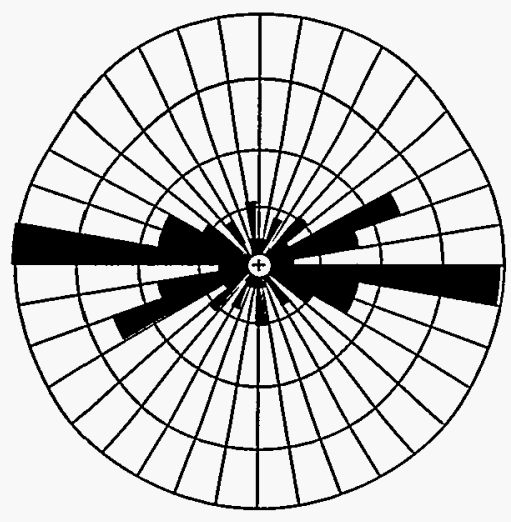

Upper $\mathbf{N}$ Wall

$\mathrm{n}=\mathbf{2 1}$

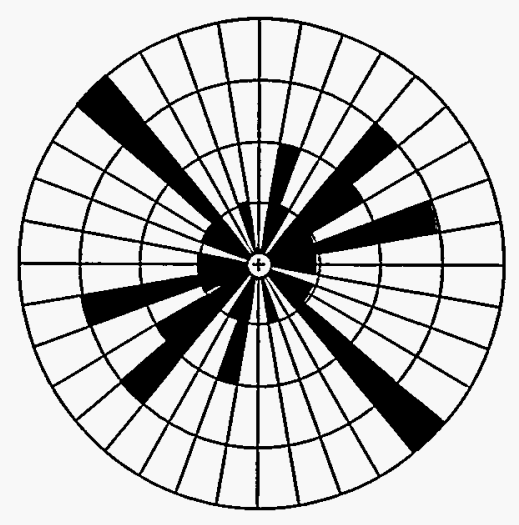

Lower $\mathbf{N}$ Wall

$\mathrm{n}=\mathbf{3 4}$

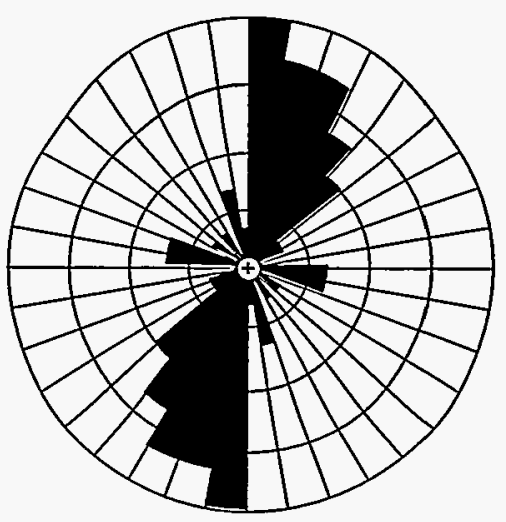

Fig. 6. Rose diagrams of fracture orientation for Pit 39 fractures, plotted in $10^{\circ}$ classes.

fracture sets centered at about $50^{\circ}(\mathrm{N} 50 \mathrm{E})$ and $165^{\circ}$ $(\mathrm{N} 15 \mathrm{~W})$ are also suggested, although the data from the two methods do not agree on these sets.

Other Pajarito Plateau Studies. Fracture orientations have been reported from many studies on the Pajarito Plateau (Purtymun and Kennedy, 1971; Rogers, 1977; Purtymun et al., 1978, 1995; Vaniman and Wohletz, 1990; Kolbe et al., 1994, 1995; Vaniman and Chipera, 1995; Wohletz, 1995, 1996; Rogers et al., 1996; Walters, 1996), and the Pit 39 data seem to be only partially consistent with data reported from other studies in respect to identification of preferred fracture orientations. Although one of the most prominent orientations for fractures in Pit 39 is roughly E-W, only a few other studies suggest preferred fracture sets oriented roughly E-W (Purtymun et al., 1995; Vaniman and Chipera, 1995; Rogers et al., 1996). Most reported data have been collected along E-W exposures, and a measurement bias imparted by the nonrandom orientations of exposures would be expected to underweight E-W fractures. For example, a correction applied by Wohletz (1995, 1996) to fractures along E-W cliff traverses in Los Alamos Canyon suggested a prominent E-W fracture set there that was not obvious in the original data. Alternatively, Rogers et al. (1996) report that a large MDA $G$ data set that should not have large measurement biases suggests random orientations to fractures and no preferred orientations. 

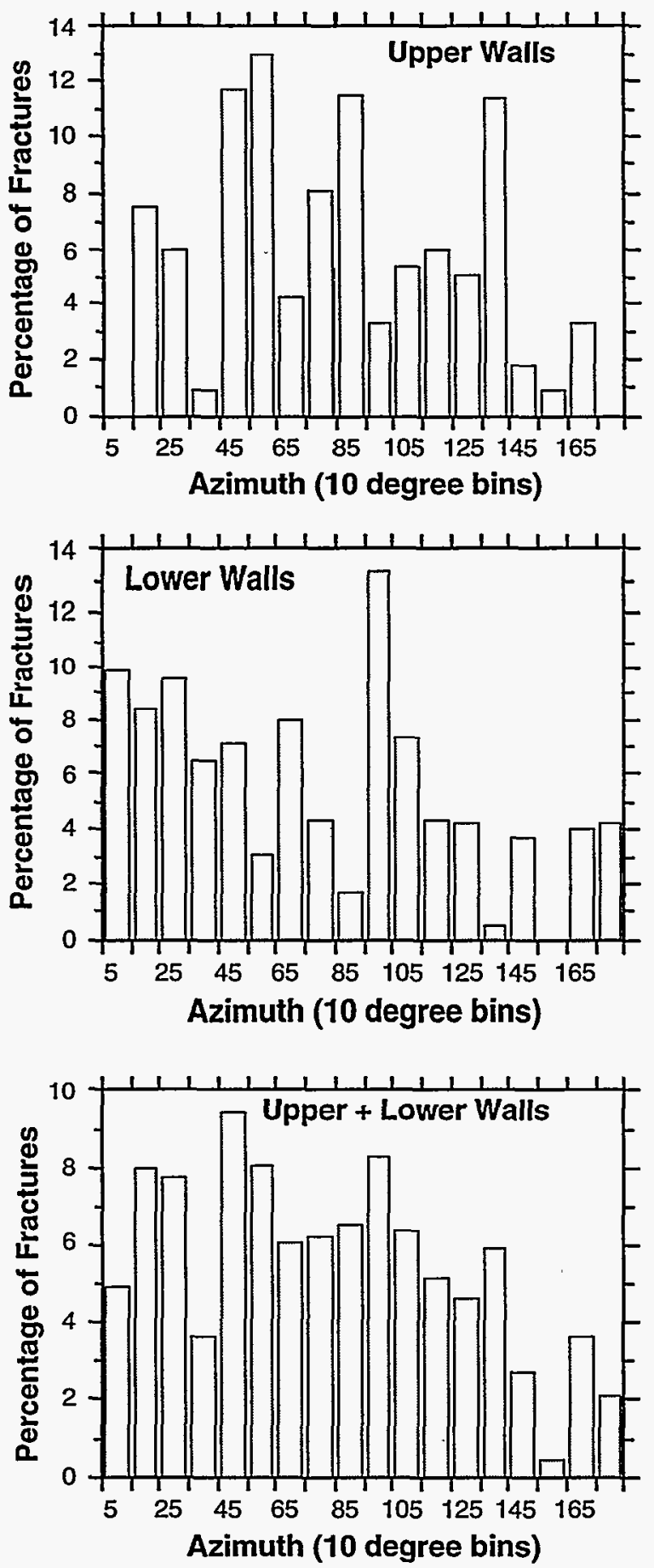

Fig. 7. Histograms of fracture azimuth, grouped into $10^{\circ}$ classes, weighting $E-W$ and $N-S$ trending walls equally (50\% assigned to walls with each orientation). In the plot combining data from the lower and upper walls, a weighting of 50\% was assigned to each data set.
Another fracture orientation that is prominent in Pit 39, roughly $\mathrm{N}-\mathrm{NE}$, is also only partially represented in other fracture data sets reported in the area (Kolbe et al., 1994, 1995; Purtymun et al., 1995; Vaniman and Chipera, 1995; Rogers et al., 1996). Because fractures with this orientation should be well represented in E-W exposures, we infer that this discrepancy is due to substantial local variability in fracture orientations across the Pajarito Plateau. That is, although large data sets may reveal preferred fracture orientations, frequent deviations from these orientations may also exist locally. Other fracture orientations that have been reported as most prominent in other studies, particularly about $40^{\circ}$ to $50^{\circ}$ (N40E-N50E) and about $130^{\circ}$ to $160^{\circ}(\mathrm{N} 20 \mathrm{~W}-\mathrm{N} 50 \mathrm{~W})$, are relatively poorly represented in Pit 39.

\section{Fracture Dip}

Pit 39. Fractures in Pit 39 are typically steeply dipping, showing similar distributions of fracture dip for data sets from both the upper and lower walls (Fig. 10). The mean fracture dip is $76^{\circ}$ and $77^{\circ}$ for the lower and upper walls, respectively, and the median fracture dips are $84^{\circ}$ and $87^{\circ}$.

To examine the data for a possible preferred direction of dip, the upper and lower walls were each divided into $\mathrm{N}-\mathrm{S}$ trending fractures (azimuth $=0^{\circ}$ to $45^{\circ}$ and $135^{\circ}$ to $180^{\circ}$ ) and $\mathrm{E}-\mathrm{W}$ trending fractures (azimuth $=45^{\circ}$ to $135^{\circ}$ ). For south and east dipping fractures, dips of $90^{\circ}$ to $180^{\circ}$ were assigned, and for north and west dipping fractures, dips of $0^{\circ}$ to $90^{\circ}$ were assigned. No preferred direction of dip is apparent in the data for upper wall fractures, with the median of both data sets being $90^{\circ}$ and with the average being $89^{\circ}$ to $90^{\circ}$ (Fig. 11). For the lower wall fractures, the data suggest slight preferential dip directions to the west and north (Fig. 11).

This apparent preferential dip direction in the lower wall suggests that inclined holes drilled to the eastsoutheast may, on average, intersect a larger number of fractures in the lower unit than would inclined holes with other orientations. Although the 

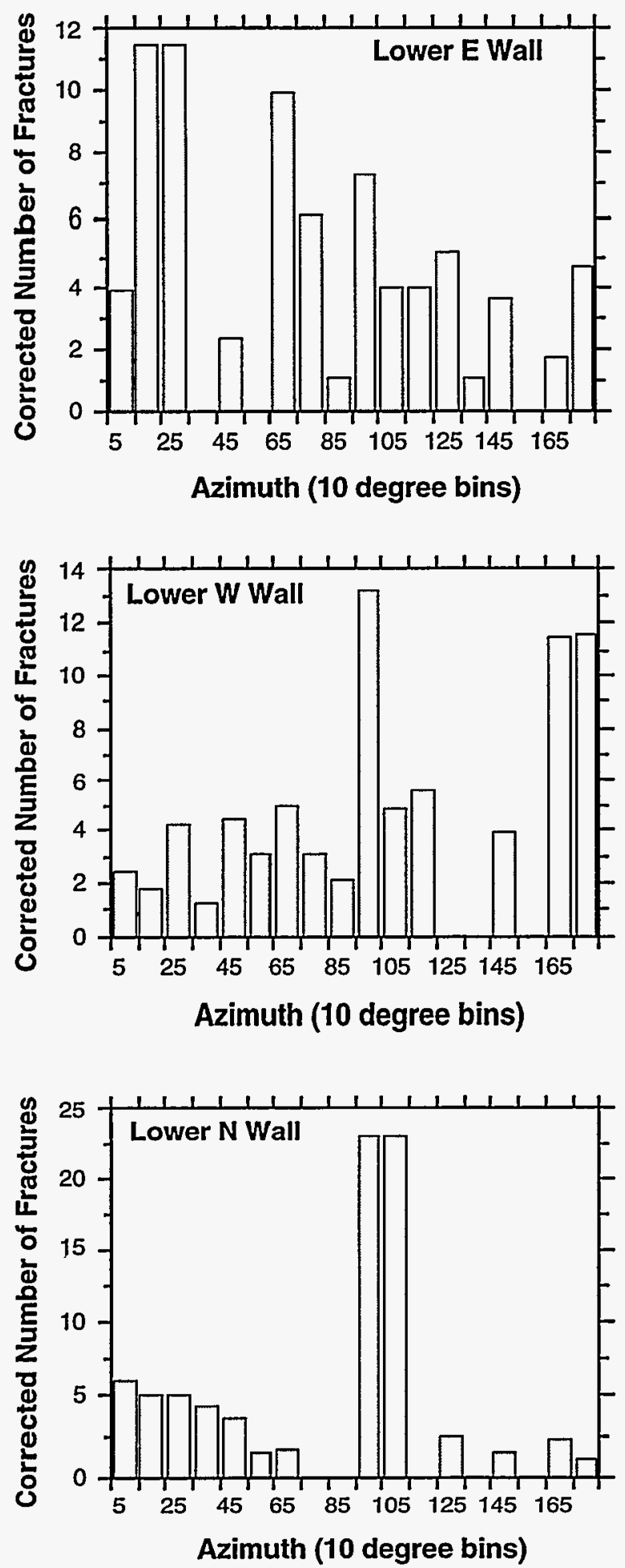
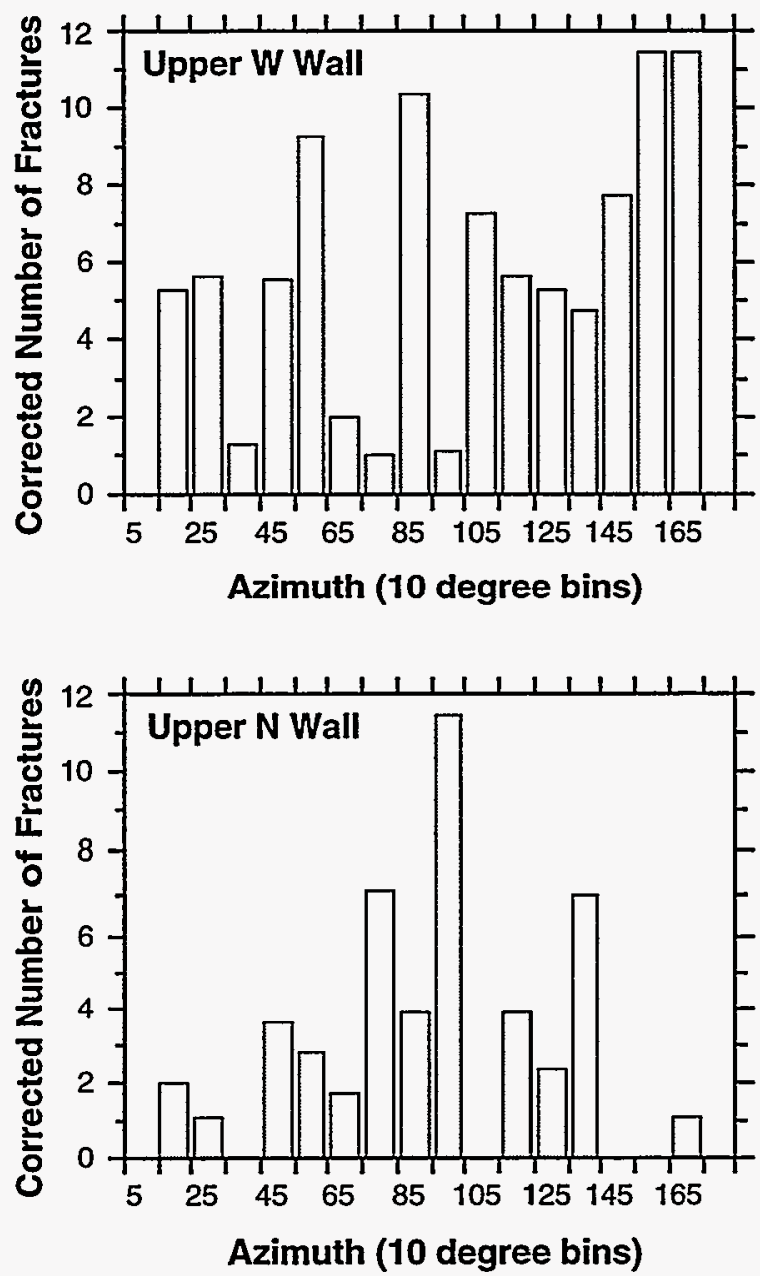

Fig. 8. Histograms of fracture azimuths for each wall, corrected for the angle of intersection between the fracture set and the exposure. Wall azimuths are $20^{\circ}(\mathrm{N} 20 \mathrm{E})$ for the east wall, $160^{\circ}(\mathrm{N} 20 \mathrm{~W})$ for the west wall, and $100^{\circ}(\mathrm{N80W})$ for the north wall. 

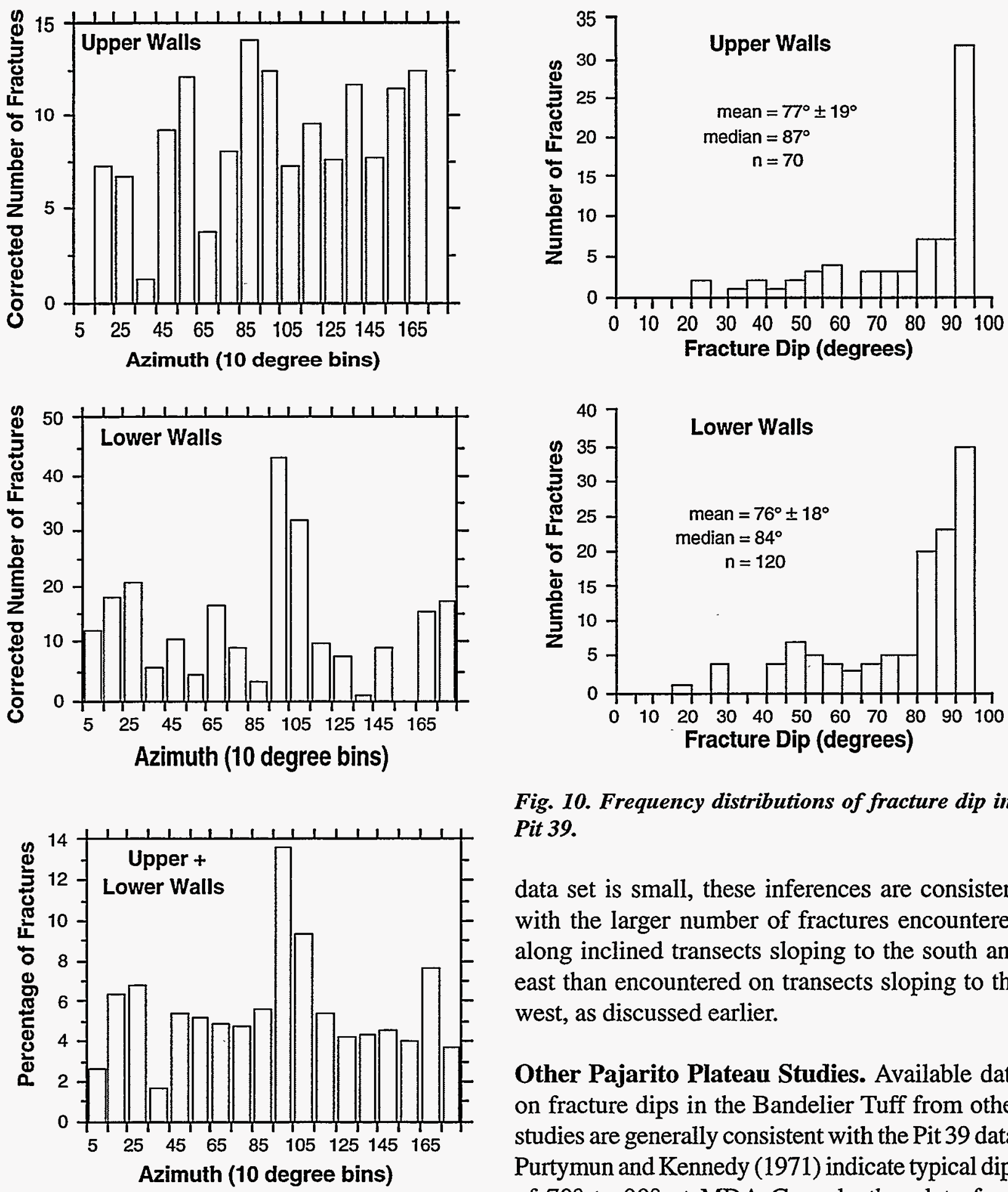

Fig. 10. Frequency distributions of fracture dip in Pit 39.

data set is small, these inferences are consistent with the larger number of fractures encountered along inclined transects sloping to the south and east than encountered on transects sloping to the west, as discussed earlier.

Other Pajarito Plateau Studies. Available data on fracture dips in the Bandelier Tuff from other studies are generally consistent with the Pit 39 data. Purtymun and Kennedy (1971) indicate typical dips of $70^{\circ}$ to $90^{\circ}$ at MDA G, and other data from MDA G summarized by Rogers (1977) indicate that $70 \%$ of the fractures in some pits dip $80^{\circ}$ or more. Purtymun et al. (1995) report typical dips of $70^{\circ}$ to $90^{\circ}$ at TA-3, and typical dips of $80^{\circ}$ to $90^{\circ}$ at TA-55. Similarly, Wohletz $(1995,1996)$ reports average dips of $68^{\circ}$ to $74^{\circ}$ for exposures adjacent to TA-21 and about $80^{\circ}$ for exposures adjacent to 

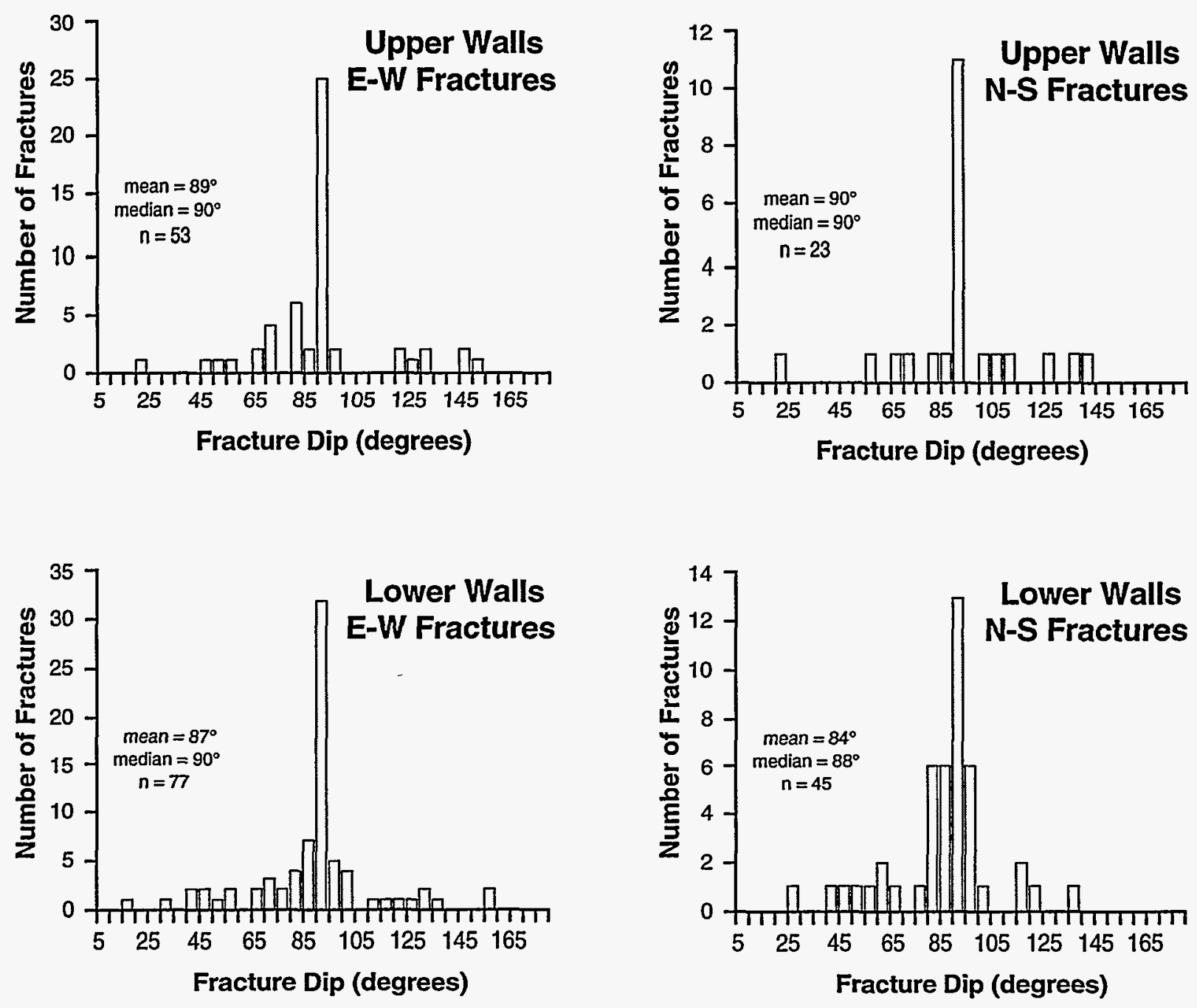

Fig. 11. Direction of dip for fractures in Pit 39. E-W fractures have azimuths of $45^{\circ}$ to $135^{\circ}$, and $N-S$ fractures have azimuths of $0^{\circ}$ to $45^{\circ}$ and $135^{\circ}$ to $180^{\circ}$.

TA-2 and TA-41 in Los Alamos Canyon. These data are similar to the average dips of $76^{\circ}$ to $77^{\circ}$ for Pit 39. Wohletz (1995) also reports preferential dips to the northwest, consistent with the possible preferential dips to the north and west measured at Pit 39.

\section{ROOTS, ROOT FOSSILS, AND FRACTURE- FILLING MATERIALS}

Fracture-filling materials in Pit 39 vary both with depth and with plan-view location. Shallower fractures ( $<10 \mathrm{ft}[3 \mathrm{~m}]$ depth) may have abundant smectite, but clay illuviation to depths greater than this is generally absent. Calcite and opal may occur at all depths, principally associated with roots or root fossils (rhizoliths). The shallower occurrence of clays and deeper penetration of calcite and opal ("calcrete" minerals) is the opposite of the observations made by Renault (1977) at pits 7 and 24 within MDA G. This difference may be important, for deep illuviation of clay, as noted in the pits studied by Renault, may indicate local fracture sets with greater potential for particulate transport.

Within Pit 39, deep penetration of roots is concentrated along the northern wall of the pit where roots are found in the deepest portions of 
the pit. Those roots that could be identified at this depth are piñon roots (Martens, 1993). The concentration of deep roots in this part of the pit may indicate a fracture set along which deep water transport has been concentrated.

Finely powdered tuff occurs in a number of fractures at all depths and is admixed with a small amount of calcite at shallower depths. This powdered tuff consists of clay-sized particles but appears to be the product of abrasive disaggregation of the vapor-phase minerals and perhaps of phenocrysts that line the fracture walls. Fractures filled with such powdered material may have experienced small amounts of displacement, leading to desegregation of the friable tuff. Such displacements are indicated by common minor faults identified along the south side of Mesita del Buey (Reneau et al., 1998).

\section{Root-Feature Distributions}

Occurrences of roots and root fossils were noted during fracture mapping. These occurrences were considered to be of some importance because of the nonuniform distribution of root features and the potential use of these features as indications of water-bearing fracture systems. Because roots are unlikely to penetrate deeply into fracture sets where water is not available, the distributions of living roots may provide one indication of watertransmissive fracture sets.

In the northern part of Pit 39, living roots were found in fractures as deep as the bottom of the pit ( $45 \mathrm{ft}$ ). This contrasts with the eastern and western walls of the pit, where roots were not found at this depth and root abundances at shallower levels were minor. Figure $2 B$ shows the distribution of those fractures that contain roots. Although it is possible that water might be transported uniformly through all fractures transecting the pit, with a chance increase in root abundance to the north, we feel that the nonuniformity in root distributions is not fortuitous.
Although root distributions are inferred to indicate those fractures in which deep infiltration was most prominent prior to the excavation of Pit 39 , it is possible that excavation has disturbed the fracture systems intersecting the pit wall, and fracture transport in the future will not be the same as in the past. The Seamist monitoring system emplaced in the pit may provide useful information on whether such disturbance has occurred. The results of this monitoring may be useful for evaluation not only of Pit 39 , but also of future pit excavations.

\section{Mineralogy of Fracture Fillings}

Several fracture fillings were analyzed by XRD to determine their mineralogy. The fracture fillings chosen for analysis are those that are typical of the fractures mapped, and their locations are shown on Figure 2A. These analyses are summarized below.

1) Samples F138 (fracture filling at $1 \mathrm{ft}$ depth, west wall of pit) and F11 (fracture filling at $41 \mathrm{ft}$ depth. east wall of pit)

These are fine-grained, gray powders that occur in both shallow and deep fractures but are most typical of the deeper $(>20 \mathrm{ft}, 6 \mathrm{~m})$ fracture fillings. The extremely fine-grained nature of these fracturefilling powders was suggestive of clay mineralogy in the field. However, XRD analysis shows that there is essentially no clay in these powders, and they consist mostly of very fine-grained material derived from the surrounding devitrified tuff. Nevertheless, the feldspar and silica-mineral particles that make up these powders are very fine grained $(1$ to $10 \mu \mathrm{m})$ and most of the fragments are clay-sized $(<4 \mu \mathrm{m})$.

The shallow gray-powder fracture sample (F138) consists of powdered feldspars, tridymite, quartz, cristobalite, and calcite with minor amounts of gypsum and hematite. Clay separation methods (grinding and centrifugation) yielded a very small proportion of smectite and kaolinite, both poorly 
crystalline. The principal authigenic mineral at this shallow depth $(1 \mathrm{ft}, 0.3 \mathrm{~m})$ is therefore calcite, with much smaller amounts of smectite. Gypsum may be introduced as an eolian component.

The deeper gray-powder fracture sample (F11) consists almost entirely of powdered feldspars, tridymite, quartz, and cristobalite with minor amounts of hematite. The only authigenic mineral present at this greater depth ( $41 \mathrm{ft}, 12.5 \mathrm{~m})$ is calcite, which occurs in minor amounts.

\section{2) Sample F142 (clay-rich fracture filling at $1 \mathrm{ft}$} depth. west wall of pit)

This sample is from a thick $(5 \mathrm{~cm})$ surface enlargement of a fracture that closes down to $8 \mathrm{~mm}$ within a few $\mathrm{ft}$ from the surface. The upper clay filling of the wider fracture is predominantly smectite, with minor amounts of detrital feldspars, tridymite, quartz, cristobalite, and hematite with some authigenic calcite. There are traces of gypsum as well, perhaps introduced as an eolian component. The dominance of smectite and the nature of the secondary mineralogic components in this sample are consistent with results of other studies on the Pajarito Plateau (Renault, 1977; Davenport, 1993; Davenport et al., 1995; Vaniman and Chipera, 1995).

3) Sample F61 (thin fracture-wall coating at $42 \mathrm{ft}$ depth, north wall of pit)

Thin coatings (1 to $3 \mathrm{~mm}$ ) such as this occur on several fracture walls at depth and are typically associated with root and root fossil occurrences. This coating predominantly consists of calcite with some opal-A.

\section{4) Sample F44 (root fossil at $17 \mathrm{ft}$ depth. NE corner of pit)}

This sample of a well-fossilized root consists entirely of opal-A.

\section{Chemistry of Root Features}

Both living roots and root fossils were examined using a SEM. Root-fossil formation includes calcite and opal precipitation within root cavities, around root walls, and replacing root cell structures. Calcite predominates, either as micrite grains or as needle-fiber crystals ( 1 to $5 \mu \mathrm{m}$ wide and up to $100 \mu \mathrm{m}$ long). The needle-fiber form is characteristic of fungal activity during root decay. Advanced stages of root fossilization (e.g., sample F44, described above) can result in complete replacement of the root structure by opal-A. Figure 12 illustrates the morphology of calcite needles and of opal-A spherules in a root fossil from fracture $F 61$, at $42 \mathrm{ft}(12.8 \mathrm{~m})$ depth on the north wall of Pit 39. Literature data on needle-fiber calcites typically show fibers with smooth or serrated outer surfaces (Verrecchia and Verrecchia, 1994), in contrast to the rugose fiber surfaces seen in Figure 12. The rugose surfaces and large diameters (up to $7 \mu \mathrm{m}$ ) of needle-fiber calcites from Pit 39 indicate that the original fungal forms have been coated by later calcite precipitation.

Clay illuviation is common at depths up to $10 \mathrm{ft}$ $(3.0 \mathrm{~m})$ but is rare or absent in the lower portions of the pit. Extensive calcite and opal-A deposition occurs around living roots and as root fossils in this upper $(10 \mathrm{ft}, 3 \mathrm{~m})$ zone. Mineralization is less abundant at greater depths (with the exception of a few fractures in the north wall). Energydispersive linescans across living root segments from the deeper portions of the north wall (Fig. 13) show that the cores of living roots from the pit bottom are dominantly Ca-rich; from other studies of piñon and juniper roots, it is likely that all of the Ca observed is present within the mineral whewellite $\left(\mathrm{CaC}_{2} \mathrm{O}_{4} \cdot \mathrm{H}_{2} \mathrm{O}\right)$ or in amorphous forms associated with $\mathrm{P}, \mathrm{Cl}$, and $\mathrm{S}$ (Vaniman et al., 1995). Opal-A (amorphous $\mathrm{SiO}_{2}$ ) is concentrated on the exterior surfaces of the roots. At Pit 39 there is little calcite associated with the living roots prior to fossilization. Calcium and silicon, the two 
A

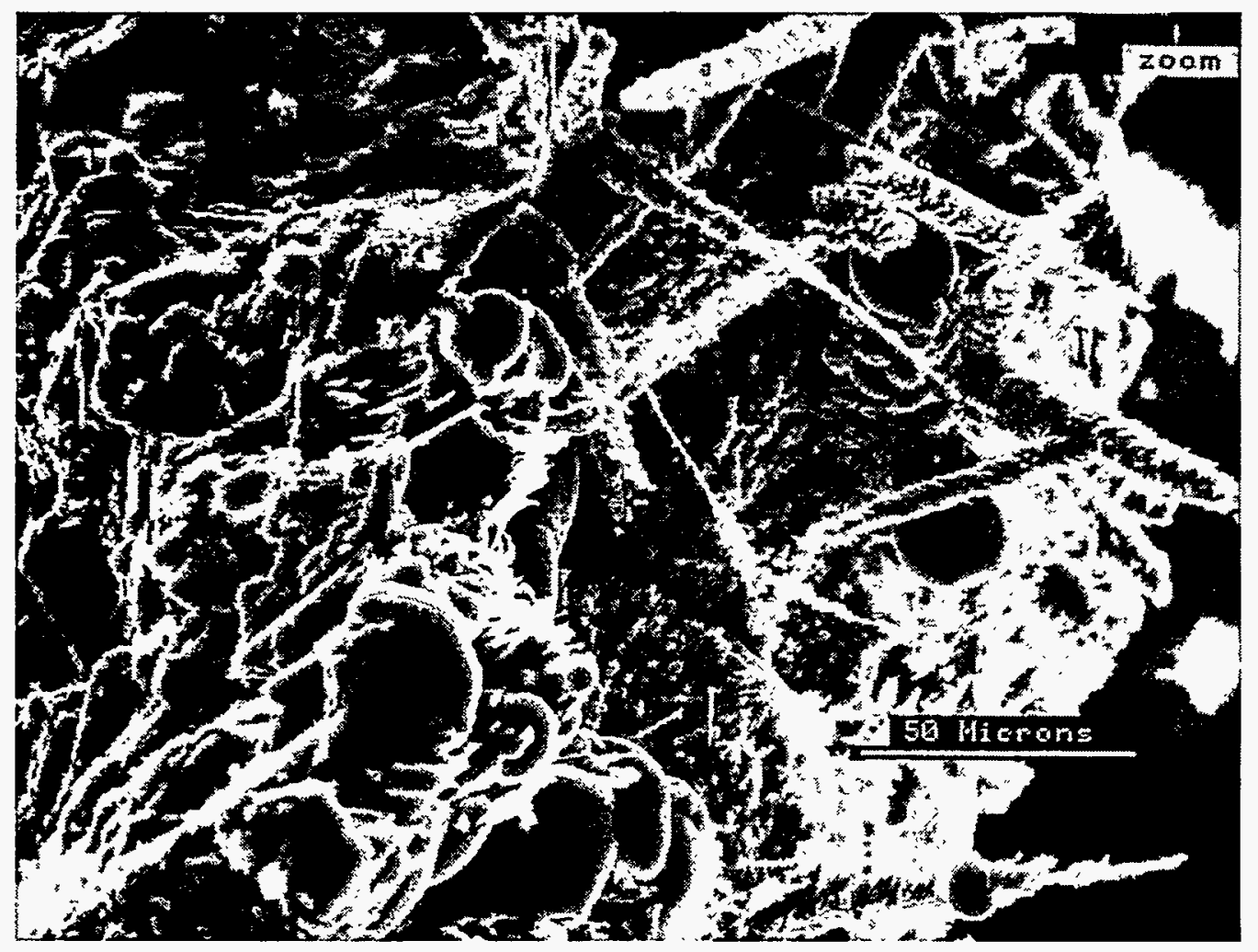

$\mathrm{B}$

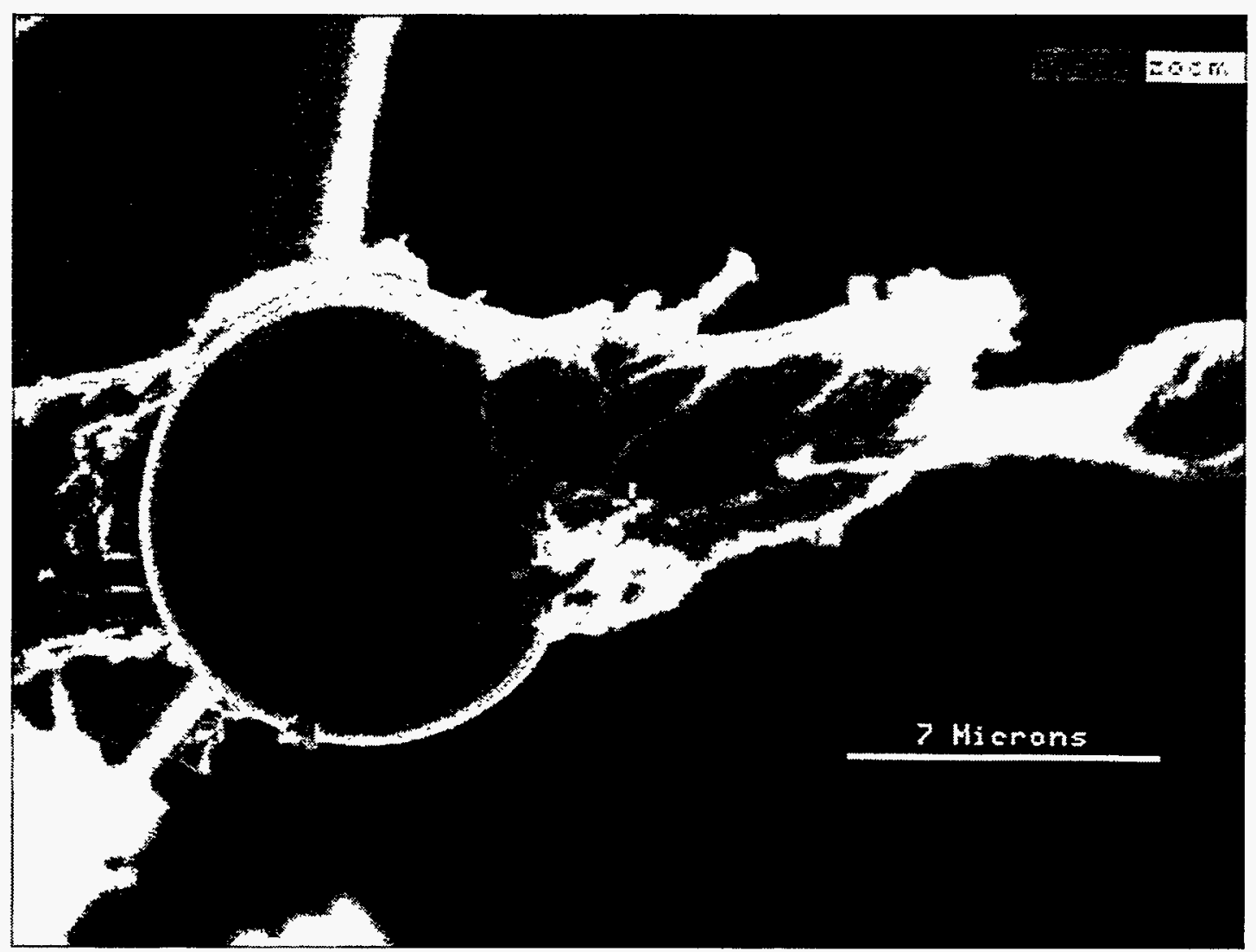

Fig. 12. SEM images of calcite and opal-A mineralization in a fossil root from 42 ft depth in the northern part of Pit 39 (sample F61, backscattered-electron images). Calcite fibers typically have tapered terminations and rugose surfaces. Opal-A occurs as small spherules, often precipitated on previously formed calcite fibers. 


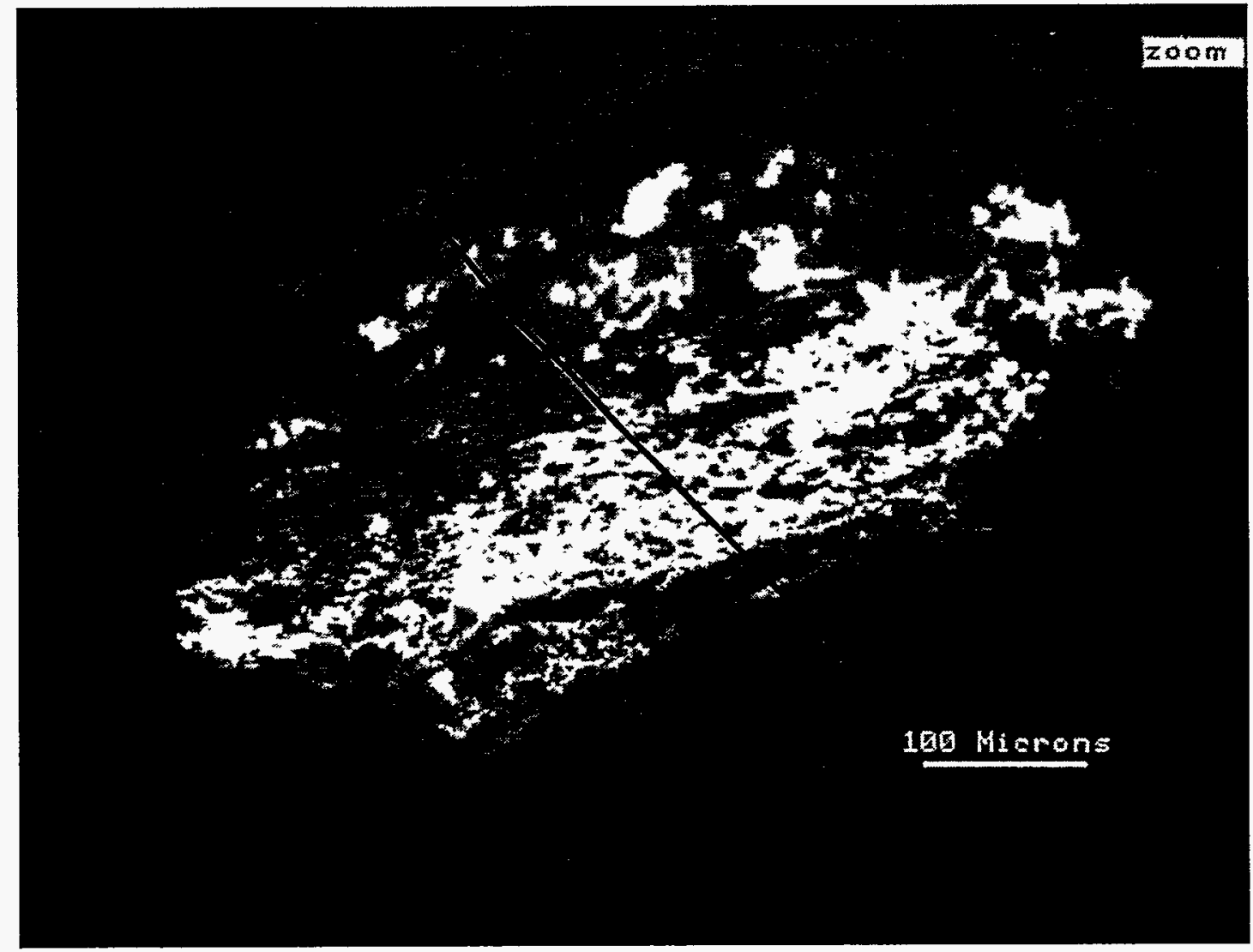

$\mathrm{B}$

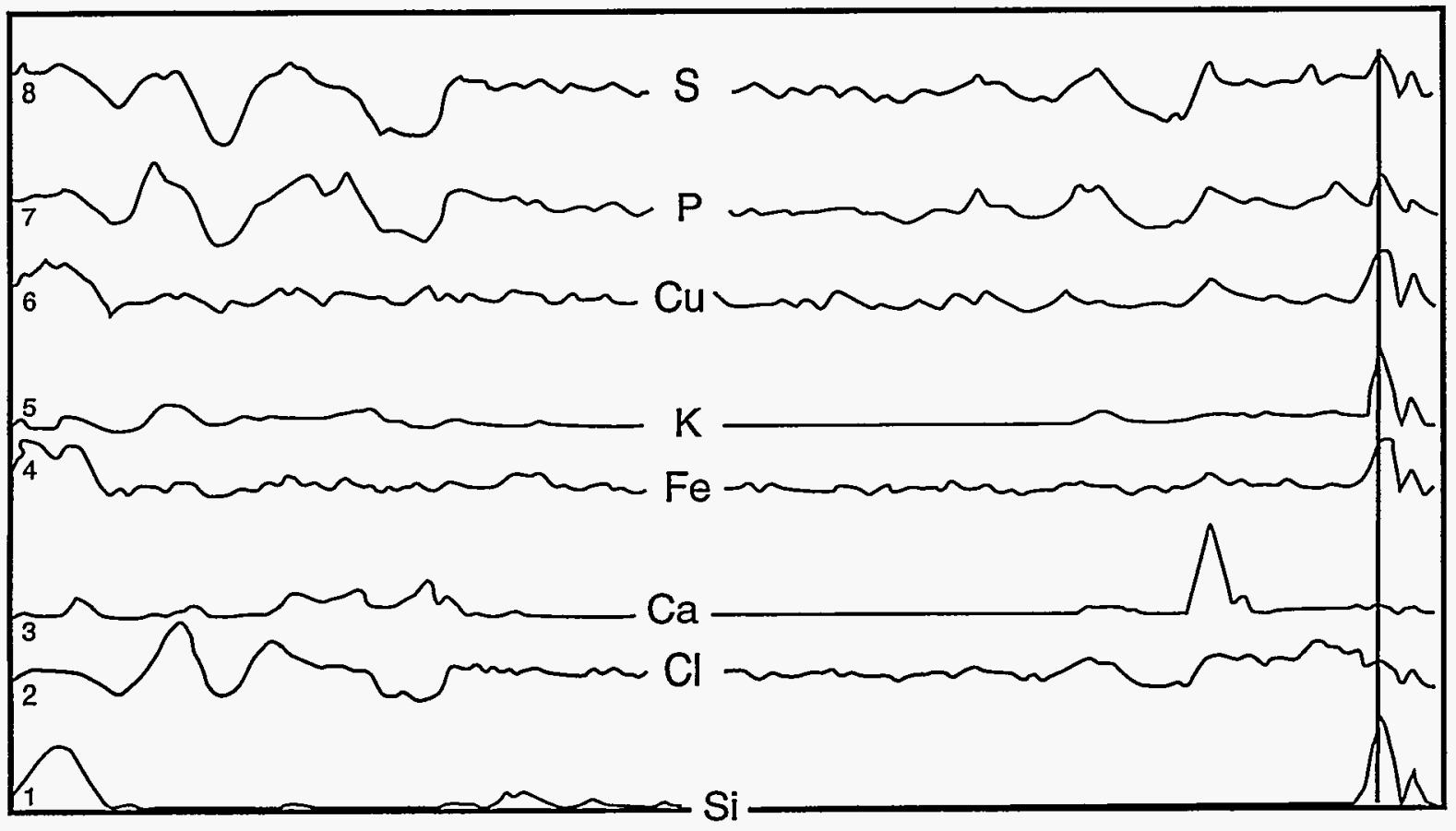

Fig. 13. SEM backscattered-electron image $(A)$ and energy-dispersive linescan $(B)$ of a living root from $41 \mathrm{ft}$ depth in the northern part of Pit 39 (sample F53). Length of linescan is $395 \mathrm{~mm}$. Opal-A (represented by peaks in the Si scan) is concentrated in the inorganic coating of the root surface. Metals (copper, iron) and potassium are concentrated in this exterior coating. Calcium, sulfur, phosphorous, and chlorine are concentrated in the interior of the root, but not in the central portion. Calcium is probably concentrated in root portions that contain the mineral whewellite. 
elements associated with whewellite and opal, are predominant, but some trace elements appear to be correlated with certain root portions:

1) $\mathrm{Cl}, \mathrm{P}$, and $\mathrm{S}$ are concentrated within portions of the root interiors.

2) Heavier metals ( $\mathrm{Fe}, \mathrm{Zn}, \mathrm{Cu})$ and $\mathrm{K}$ are concentrated in the inorganic opaline coatings on the root surfaces.

Root chemistry, especially metal retention effects and possible metal complexation around roots, may be an important factor in long-term contaminant transport interactions.

\section{Implications of Mineralogic and Root Studies}

Mineralogic studies of fracture fillings suggest that deep $(>20 \mathrm{ft}, 6 \mathrm{~m}$ ) fracture fillings consist only of powdered tuff unless root penetration and the products of root decay introduce calcite and, to a lesser extent, opal-A as biologically mediated precipitates. Such deep mineral deposits in fractures are limited to the northern part of Pit 39, where penetration by living roots is common. This northern part of the pit may mark a zone of infiltration of water from the surface.

Clay minerals-predominantly smectite, with rare kaolinite - are abundant only in the near-surface; downward transport of clay-size particles by illuviation is largely ineffective over distances greater than $10 \mathrm{ft}(3 \mathrm{~m})$ at Pit 39.

The origins of the fine gray tuff powder that occurs in several other fractures in various parts of the pit are somewhat enigmatic. The absence of clay illuviation to depths where these powders are common indicates that they are not formed by winnowing and downward filtration of tuff fines. Local abrasion and size reduction of the friable host tuff along preferred fractures is a more likely explanation. This explanation, however, requires some differential movement along the fractures that contain the powders. These fractures may therefore be those that have moved to accommodate dispersed fault offsets, as seen in offset surge beds in the cliff margin along the south side of Mesita del Buey (Reneau et al., 1998). The amount of fracture movement required to create these powders need not be great, for the particle size range (1 to $10 \mu \mathrm{m}$ ) is not significantly smaller than that of the fine-grained devitrification crystals that form the matrix of the host tuff.

\section{SUMMARY}

Pit 39 at MDA G, TA-54, exposes two ash flows within unit 2 of the Tshirege Member of the Bandelier Tuff; fractures were mapped and described within each flow unit. The fractures are generally steeply dipping, with mean dips of $76^{\circ}$ and $77^{\circ}$ and median dips of $84^{\circ}$ and $87^{\circ}$ for the lower and upper flow units, respectively. Preferential dips to the north and east in the lower unit are suggested by the data, in turn suggesting that inclined drill holes oriented to the southeast may optimize intersections with fractures. Fracture apertures are typically small, with median values of about $3 \mathrm{~mm}$ for both units and average apertures of 3 to $5 \mathrm{~mm}$. Average fracture spacing ranges from 3.2 to $4.2 \mathrm{ft}$ (1.0 to $1.3 \mathrm{~m}$ ), and median fracture spacing ranges from 1.9 to $4.0 \mathrm{ft}(0.6$ to $1.2 \mathrm{~m})$. Slight differences are suggested between fracture spacing between the upper and lower units, with a higher percentage of fracture spacings under $2 \mathrm{ft}$ $(0.6 \mathrm{~m})$ and a higher maximum fracture spacing $(14 \mathrm{ft}, 4.3 \mathrm{~m})$ in the upper unit, although average spacing is similar between the units.

The measurements of fracture dip and aperture at Pit 39 appear to be consistent with previous measurements from other pits at MDA G. The measurements of fracture spacing at Pit 39, however, indicate more closely spaced fractures than recorded at other pits, although the Pit 39 data are similar to data from horizontal core holes obtained beneath Pit 3 at MDA G (Purtymun et al., 1978). This discrepancy may be due to an incomplete logging of minor fractures in the pit walls in previous studies.

Data on fracture orientation from Pit 39 suggest fracture sets centered at about $95^{\circ}(\mathrm{N} 85 \mathrm{~W})$ and $20^{\circ}$ 
(N20E) azimuth, with possible additional fracture sets centered at about $50^{\circ}$ (N50E) and $165^{\circ}$ (N15W). However, these data may not be reliable due to the small sample size and the need to correct for biases imparted by the nonrandom orientation of pit walls. Similar biases have probably affected other data sets on fracture orientation from the Bandelier Tuff. For example, the most prominent fracture set at Pit 39, with extensive north-south walls, is oriented roughly east-west, whereas other fracture data obtained from east-west transects do not show prominent east-west fracture sets, a bias also shown by Rogers et al. (1996).

The minerals and roots that fill or line fractures provide information on the depths and nature of potential transport, as well as on possible offset along fractures. Root penetration to the bottom of the pit can be used to infer fracture zones that held intermittent water prior to pit excavation; roots are unlikely to have penetrated to this depth if the fractures were permanently dry. However, the general absence of clay illuviation in any fractures to depths $>10$ to $20 \mathrm{ft}$ ( 3 to $6 \mathrm{~m}$ ) suggests that particulate transport has not been effective in any of the fractures or fracture sets at Pit 39. Fractures that generally lack authigenic minerals but are filled with powdered tuff may have suffered small-scale displacements sufficient to disaggregate the wallrock tuff.

\section{ACKNOWLEDGMENTS}

The authors thank Dave Broxton for assistance with the field work; Anthony Garcia and John Carney for figure preparation; Steve Chipera for XRD analyses; Steve Francis for arranging access to Pit 39; Jamie Gardner, Bob Gilkeson, Diana Hollis, Don Krier, Don Neeper, and Cheryl Rofer for providing encouragement and support for this study; Scott Martens for root identification; Mable Amador for editing; Lanny Piotrowski for compositing of the final report; and Giday WoldeGabriel for review comments. This work was supported by the Los Alamos National Laboratory Environmental Restoration Project, as part of site characterization activities for TA-54 (Operable
Unit 1148) and the Framework Studies program within the Earth Science Technical Team.

\section{REFERENCES}

Broxton, D. E., and Reneau, S. L., 1995, Stratigraphic Nomenclature of the Bandelier Tuff for the Environmental Restoration Project at Los Alamos National Laboratory: Los Alamos National Laboratory report LA-13010-MS, Los Alamos, New Mexico, 21 pp.

Davenport, D. W., 1993, Micromorphology, Mineralogy, and Genesis of Soils and Fracture Fills on the Pajarito Plateau, New Mexico: Ph.D. thesis, Texas Tech University, Lubbock, 109 pp.

Davenport, D. W., Wilcox, B. P., and Allen, B. L., 1995, Micromorphology of Pedogenically Derived Fracture Fills in Bandelier Tuff, New Mexico: Soil Science Society of America Journal, v. 59, pp. 1672-1683.

Kolbe, T., Sawyer, J., Gorton, A., Olig, S., Simpson, D., Fenton, C., Reneau, S., Carney, J., Bott, J., and Wong, I., 1994, Evaluation of the Potential for Surface Faulting at the Proposed Mixed Waste Disposal Facility, TA-67: Woodward-Clyde Federal Services, Oakland, California, 3 volumes.

Kolbe, T., Sawyer, J., Springer, J., Olig, S., Reneau, S., Hemphill-Haley, M., and Wong, I., 1995, Evaluation of the Potential for Surface Faulting at TA-63: Woodward-Clyde Federal Services, Oakland, California.

Martens, S., 1993, personnel communication, Los Alamos National Laboratory.

Neeper, D. A., and Gilkeson, R. H., 1996, The Influence of Topography, Stratigraphy, and Barometric Venting on the Hydrology of Unsaturated Bandelier Tuff, in Goff, F., Kues, B. S., Rogers, M. A., McFadden, L. D., and Gardner, J. N., Eds., The Jemez Mountains Region: New Mexico Geological Society Forty-Seventh Annual Field Conference Guidebook, pp. 427-432. 
Purtymun, W. D., and Kennedy, W. R., 1971, Geology and Hydrology of Mesita del Buey: Los Alamos Scientific Laboratory report LA-4660, Los Alamos, New Mexico, 12 pp.

Purtymun, W. D., Wheeler, M. L., and Rogers, M. A., 1978, Geologic Description of Cores from Holes P-3 MH-1 through P-3 MH-5, Area G, Technical Area 54: Los Alamos Scientific Laboratory informal report LA-7308-MS, Los Alamos, New Mexico, 13 pp.

Purtymun, W. D., Koenig, E., Morgan, T., and Sagon, E., 1995, Joint Orientations and Characteristics as Observed in a Trench Excavated near TA-3 and a Basement Excavated at TA-55: Los Alamos National Laboratory report LA-13036MS, Los Alamos, New Mexico, 42 pp.

Renault, J., 1977, Report on the Examination of Fracture Fillings in Disposal Pits No. 7 and No. 24, Los Alamos Scientific Laboratory, in Rogers, M. A., Ed., History and Environmental Setting of LASL Near-Surface Land Disposal Facilities for Radioactive Wastes (Areas A, B, C, D, E, F, G, and T): A Source Document: Los Alamos Scientific Laboratory informal report LA-6848-MS, Los Alamos, New Mexico, v. I, pp. G-73-G-80.

Reneau, S. L., Kolbe, T., Simpson, D., Carney, J. S., Gardner, J. N., Olig, S. S., and Vaniman, D. T., 1995, Surficial Materials and Structure at Pajarito Mesa, in Reneau, S. L., and Raymond, R., Jr., Eds., Geological Site Characterization for the Proposed Mixed Waste Disposal Facility, Los Alamos National Laboratory: Los Alamos National Laboratory report LA-13089-MS, Los Alamos, New Mexico, pp. 31-69.

Reneau, S. L., Broxton, D. E., Carney, J. S., and LaDelfe, C., 1998, Structure of the Tshirege Member of the Bandelier Tuff at Mesita del Buey, Technical Area 54, Los Alamos National Laboratory: Los Alamos National Laboratory report LA-13538-MS, Los Alamos, New Mexico.
Rogers, M. A., 1977, History and Environmental Setting of LASL Near-Surface Land Disposal Facilities for Radioactive Wastes (Areas A, B, C, D, E, F, G, and T): A Source Document: Los Alamos Scientific Laboratory informal report LA-6848-MS, v. I, Los Alamos, New Mexico.

Rogers, M. A., 1995, Geologic Map of the Los Alamos National Laboratory Reservation: New Mexico Environment Department, Santa Fe.

Rogers, M. A., Budding, K. E., and Christie, C. V. L., 1996, Distinguishing Tectonic Joints from Cooling Joints in the Bandelier Tuff (Pleistocene), Pajarito Plateau, Los Alamos County, New Mexico, in Goff, F., Kues, B. S., Rogers, M. A., McFadden, L. D., and Gardner, J. N., Eds., The Jemez Mountains Region: New Mexico Geological Society Forty-Seventh Annual Field Conference Guidebook, pp. 293-301.

Terzaghi, R. D., 1965, Sources of Error in Joint Surveys: Geotechnique, v. 5, pp. 287-304.

Trocki, L., 1976, Los Alamos Scientific Laboratory internal memo to Margaret Anne Rogers, January 8, 1976, Subject: Photographs of Pit 20, TA-54, with Geologic Explanations. Symbol: H8-7-76.

Turin, H. J., and Rosenberg, N. D., 1996, A Conceptual Model for Flow in the Vadose Zone beneath the Finger Mesas of the Pajarito Plateau, in Goff, F., Kues, B. S., Rogers, M. A., McFadden, L. D., and Gardner, J. N., Eds., The Jemez Mountains Region: New Mexico Geological Society Forty-Seventh Annual Field Conference Guidebook, pp. 74-76.

Vaniman, D., and Chipera, S., 1995, MesaPenetrating Fractures, Fracture Mineralogy, and Projected Fault Traces at Pajarito Mesa, in Reneau, S. L., and Raymond, R., Jr., Eds., Geological Site Characterization for the Proposed Mixed Waste Disposal Facility: Los Alamos National Laboratory report LA-13089-MS, Los Alamos, New Mexico, pp. 71-85. 
Vaniman, D., and Wohletz, K., 1990, Results from Geologic Mapping and Fracture Measurements around the TA-55 Area: Los Alamos National Laboratory memo EES1-SH90-17, Los Alamos, New Mexico, 23 pp.

Vaniman, D., Chipera, S., and Bish, D. L., 1995, Petrography, Mineralogy, and Chemistry of Calcite-Silica Deposits at Exile Hill, Nevada, Compared with Local Spring Deposits: Los Alamos National Laboratory report LA-13096MS, Los Alamos, New Mexico, 70 pp.

Verrecchia, E. P., and Verrecchia, K. E., 1994, Needle-Fiber Calcite: A Critical Review and Proposed Classification: Journal of Sedimentary Research, v. A64, pp. 650-664.

Walters, M. C., 1996, Fracture Analysis of the Bandelier Tuff, Pajarito Plateau, North-Central Rio Grande Rift, New Mexico: M.S. thesis, Texas Christian University, Forth Worth, 91 pp.

Wohletz, K., 1995, Measurement and Analysis of Rock Fractures in the Tshirege Member of the Bandelier Tuff along Los Alamos Canyon Adjacent to TA-21, in Broxton, D. E., and Eller, P. G., Eds., Earth Science Investigations For Environmental Restoration-Los Alamos National Laboratory Technical Area 21: Los Alamos National Laboratory report LA-12934-MS, Los Alamos, New Mexico, pp. 10-31.

Wohletz, K., 1996, Fracture Characterization of the Bandelier Tuff in OU-1098 (TA-2 and TA-41): Los Alamos National Laboratory Report LA-13194MS, Los Alamos, New Mexico, 19 pp. 